\title{
Coupling of electrochemical, electrogravimetric and surface analysis techniques to study dithiocarbamate / bronze interactions in chloride media
}

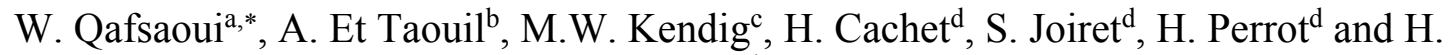 \\ Takenouti $^{\mathrm{d}}$ \\ a Laboratoire de l'Eau et de l'Environnement, Faculté des Sciences d'El Jadida, BP 20, \\ 24000 El Jadida, Morocco.wqafsaoui@gmail.com \\ bInstitut UTINAM, UMR 6213 CNRS, Université de Bourgogne Franche-Comté, 30 Avenue \\ de 1'Observatoire, 25009 Besançon Cedex, France. abdeslam.et taouil@univ-fcomte.fr \\ 'Kendig Research Associates LLC, 496 Hillsborough, Thousand Oaks, CA 91361. \\ USA, martin.kendig@verizon.net \\ ${ }^{\text {d} S o r b o n n e ~ U n i v e r s i t e ́ s, ~ U P M C ~ U n i v ~ P a r i s ~ 06, ~ C N R S, ~ L a b o r a t o i r e ~ I n t e r f a c e s ~ e t ~ S y s t e ̀ m e s ~}$ \\ Electrochimiques, 4 place Jussieu, F-75005, Paris, France. \\ hubert.cachet@upmc.fr; suzanne.joiret@upmc.fr; hubert.perrot@upmc.fr; \\ hisasi.takenouti@upmc.fr
}

\begin{abstract}
Interaction between ammonium pyrrolidinedithiocarbamate (PDTC) and bronze in $30 \mathrm{~g} \mathrm{~L}^{-1}$ $\mathrm{NaCl}$ was investigated at several concentrations between 0.1 and $10 \mathrm{mM}$ by means of various electrochemical and spectroscopic techniques. Electrochemical measurements revealed a fast adsorption process of PDTC on $\mathrm{Cu}$ and $\mathrm{Pb}$ and the formation of a thick insulating and protective film with a high surface coverage. At high concentrations, PDTC prevents oxides formation. Surface analyses confirm PDTC adsorption on bronze mainly via interaction between sulphur atoms and $\mathrm{Cu}$ sites to form $\mathrm{Cu}$-PDTC complex.
\end{abstract}

Keywords: A. Bronze, B. Polarization, B. EIS, B. Raman spectroscopy, B. XPS, C. Neutral inhibition.

* Corresponding author: Fax: +212.523 3421 87; E-mail: wqafsaoui@gmail.com 


\section{Introduction}

Bronzes ( $\mathrm{Cu}-\mathrm{Sn}$ based alloys) are among the first alloys developed by mankind to make different tools especially sculptures, weapons and armors. Nowadays, they are still widely used in metal industry in various application area including networking sectors [1-3] or lithium battery electrode materials $[4,5]$ thanks to their good conductivity and resistance to corrosion. Bronzes are copper alloys containing generally 1 to $10 \%$ of tin. They also may contain other elements such as lead, zinc, manganese, aluminium, silicon or iron depending on the variety. Mechanical properties strongly depend on the composition of bronze, especially the amount of tin which make it more resistant to wear.

In natural environments (soil, sea, atmosphere, etc.), the bronze surface undergoes corrosion and becomes overtime covered by a spontaneous degradation layer named "patina"[6-8] and exhibiting a passive behaviour. Indeed, many archeological bronze artefacts were properly conserved through formation of thick corrosion products layer formed while the object was in long contact with various media. Nevertheless, when the archeological object is extracted, sudden change of environment can accelerate corrosion process and may lead to fast complete decomposition of the object. As a consequence, methods for improving protection of bronze substrate or the reinforcement of protective property of patina layer are needed to offer less control to this phenomenon. In order to do so, the use of corrosion inhibitors has proven its efficiency and presents many advantages like easiness of application and reasonable cost.

Dermaj et al. studied the effects of an organic corrosion inhibitor: 3-phenyl-1,2,4-triazole-5thione on corrosion behaviour of a bronze. They evidenced an inhibiting effect increasing with both inhibitor concentration and sample immersion time [9]. Other works $[10,11]$ were devoted to the effects of organic inhibitors on copper corrosion as the corrosion of bronze is assimilated to that of copper since corrosion products are mainly copper mineral compounds [6-8]. Chemical structure and adsorption mode are important parameters in term of corrosion 
protection efficiency. The presence of heteroatoms like sulphur, nitrogen or phosphorus are of importance in chemical structure of inhibitor to permit binding with copper substrate [12]. Various works report the efficiency of sulphur-containing molecules for copper corrosion inhibition [13-20]. Heteroaromatic compounds have been particularly studied and proved to provide good protection. Among them, benzotriazole (BTAH) is one of the most famous [2125]. A mechanism involving the formation of a $\mathrm{Cu}^{\mathrm{I}}$-BTA complex was proposed [26]. The formation of such $\mathrm{Cu}^{\mathrm{I}}$-organic complex was also observed for other organic inhibitors such as mercaptobenzothiazole [16] or methyl mercapto-phenyl amino butanate [27]. Among the innoxious thiadiazole derivatives, 2-amino-5-mercapto-1,3,4-thiadiazole [12, 28], 2-amino-5ethylthio-1,3,4-thiadiazole [29, 30], and 2-acetamino-5-mercapto-1,3,4-thiadiazole [31] showed good corrosion inhibitive effect on copper or bronze in different aggressive media. For several years, the non-toxic ammonium pyrrolidinedithiocarbamate (PDTC), used in agriculture and medicine [32], has risen interests as corrosion inhibitor: this compound proved to bring efficient corrosion inhibition towards steel corrosion [33]. Recent studies investigated the use of PDTC as corrosion inhibitor for copper. It was shown that PDTC forms a selfassembled layer through sulphur/copper interactions [34]. In previous works we showed that the protective effect of PDTC might be explained by the formation of a highly stable $\mathrm{Cu}^{\mathrm{I}}$ PDTC complex on copper surface that leads to decrease in rate of anodic dissolution and of oxygen reduction reaction [35,36]. Moreover, we carried out similar studies on AA 2024-T3 aluminium alloy that showed good corrosion protection by PDTC thanks to the formation of an adsorbed layer on $\mathrm{Cu}$-rich particles [37].

As far as we know, no study has been dedicated to corrosion protection of bronze by PDTC. Therefore, the aim of this work is to investigate the behaviour of PDTC modified bronze samples exposed to corrosive conditions i.e. chloride medium. Different electrochemical and spectroscopic techniques were used to study the adsorption of PDTC on bronze, the chemical 
structure of the grafted molecule, the surface morphology and the behavior of the bronze/solution interface in the presence of different concentrations of PDTC.

\section{Experimental methods}

\subsection{Chemicals and materials}

All chemicals (sodium chloride and ammonium pyrrolidinedithiocarbamate) were purchased form Sigma Aldrich (analytical grade) and used as received without further purification. The disk electrodes were made of $5 \mathrm{~mm}$ diameter cylindrical rods of pure $\mathrm{Cu}, \mathrm{Sn}$, $\mathrm{Pb}, \mathrm{Zn}$ (Goodfellow, 99.999\% of quality) and Bronze B3 which is an industrial bronze used in aerospace and automobile industries, containing 10.5 to $13 \mathrm{in} \mathrm{wt} \%$ of $\mathrm{Sn}$ and corresponding to the AFNOR norm "CuSn12". Its composition is given in table 1. Figure 1 clearly evidenced a dendritic structure and non-miscible lead (white globules in Fig. 1a). The center of the dendrite (region $\mathrm{A}$ ) is rich in $\mathrm{Cu}$ and its periphery (region $\mathrm{B}$ ) is rich in $\mathrm{Sn}$ (Figure $1 \mathrm{~b}$ ). The material is thus an alpha-cored bronze. The dendrite composition, determined by EDS analysis, is reported in table 2. Moreover, the low amounts of $\mathrm{Zn}$ and $\mathrm{Ni}$ are uniformly distributed (Fig. 1c and d) in the $\mathrm{Cu}-\mathrm{Sn}$ matrix in contrast to $\mathrm{Pb}$ (Fig. 1e and f) which is localized in the interdentritic spaces.

The materials rods were embedded into allylic resin or a thermal shrinking sheath. Prior to this preparation, the lateral part of the cylinder rod was coated with a cataphoretic paint (PGG W975 + G323) to avoid the electrolyte infiltration. The electrode surface was then abraded under running water just before experiments, by rotating silicon carbide paper up to 1200 grade, and then rinsed thoroughly with deionized water.

\subsection{Electrochemical measurements}

Electrochemical measurements were carried out in aqueous solutions in a conventional three-electrode cell, using a Gamry potentiostat/galvanostat Model FAS-1 or 300C. The 
reference electrode was a saturated calomel electrode (SCE) and all the potentials measured were referred to SCE. The counter electrode was a platinum grid of a large surface area set close to the cell wall. The working disk electrode was faced towards the cell bottom under stationary conditions without electrolyte stirring. Test solution was $30 \mathrm{~g} \mathrm{~L}^{-1} \mathrm{NaCl}$ to which $10^{-4}, 10^{-3}$ or $10^{-2} \mathrm{~mol} \mathrm{~L}^{-1}$ of PDTC was added as corrosion inhibitor. For each experiment, 100 $\mathrm{mL}$ of electrolyte was used. The corrosion test was carried out under temperature control $\left(20^{\circ} \mathrm{C}\right)$ without purging dissolved oxygen. Three replica experiments were carried out for each experimental condition.

\subsubsection{Electrochemical polarization}

Polarization measurements were performed after one hour immersion in the test solution with or without PDTC. The curves were plotted from two independent measurements in a new test solution for each run: one from the open circuit potential towards about $-2 \mathrm{~V} /$ $\mathrm{SCE}$, and another from the open circuit potential to about $+1.5 \mathrm{~V} / \mathrm{SCE}$ at a potential scan rate of $1 \mathrm{mV} \mathrm{s}^{-1}$.

\subsubsection{Electrochemical impedance}

The impedance measurements were performed with $10 \mathrm{mV}_{\mathrm{rms}}$ from $100 \mathrm{kHz}$ to 10 $\mathrm{mHz}$ taking 10 points per decade at different immersion times up to 24 hours. Experiments were carried out at open-circuit potential. The data were fitted by Simad software, a lab-made software using a simplex regression method.

\subsubsection{Electrochemical Quartz Crystal Microbalance}

For EQCM (Electrochemical Quartz Crystal Microbalance) experiments, two $0.2 \mathrm{~cm}^{2}$ gold electrodes were vapour deposited on both faces of the quartz crystal blade to impose an electrical field for oscillation. One of the faces was used as a working electrode, and for this purpose, thin layers of bronze were vapour deposited onto the gold electrode through radio 
frequency plasma assisted sputtering from an industrial bronze target. Sputtering, carried out under $2 \mathrm{~Pa}$ of argon gas, lasted 20 minutes producing sputter-deposited bronze of about $1 \mu \mathrm{m}$ thick. Figure 2 shows the surface morphology of the alloy deposit. Note that the deposit appeared homogeneous without enriched regions in a dendritic structure. Clearly, the composition and microstructure of the vapour deposited layer differ from those of the solid alloy. However it is interesting to see how PDTC interacts with the uniformly dispersed alloying elements.

The nominal resonant oscillation frequency of the quartz blade was $6 \mathrm{MHz}$. Measurements were carried out with a lab-made device and monitoring program.

\subsection{Surface analyses}

\subsubsection{Scanning Electron Microscopy (SEM) / Energy Dispersive Spectroscopy (EDS)}

The surface morphology and the composition of the surface films were investigated using a field emission gun scanning microscope (FEG-SEM, Zeiss, Ultra 55) coupled with energy-dispersive X-ray spectroscopy (EDX). Element analyses were performed with a Quantax Bruker detector and data were analyzed by the Bruker Esprit software.

\subsubsection{Raman micro-spectroscopy}

Raman micro-spectroscopy analyses were carried out with a Labram-Jobin-Yvon spectrometer. The samples were irradiated with a He-Ne laser at $\lambda=632.8 \mathrm{~nm}$. The laser power was varied between 0.1 and $1 \mathrm{~mW}$ to avoid any thermal effect on sample during the analyses. A confocal microscope was used and the investigated area was limited to $5 \mu \mathrm{m}^{2}$ using an Olympus $80 \times$ Ultra Long Working Distance (ULWD) objective lens. 


\subsubsection{X-ray photoelectron spectroscopy (XPS)}

XPS experiments were performed with an ESCA + Omicron. An Al Ka anode (1486.6 $\mathrm{eV}$ ) was used, operated at $300 \mathrm{~W}$. The spectrometer was calibrated against $\mathrm{C}_{1 \mathrm{~s}}$ at $284.7 \pm 0.1$ $\mathrm{eV}$. Data were acquired with $0.1 \mathrm{eV}$ steps. The detection angle was generally normal to the surface. The pressure in the UHV analysis chamber was less than $10^{-7} \mathrm{~Pa}$.

\section{Results and discussion}

\subsection{Electrochemical measurements}

\subsubsection{Potentiodynamic polarization}

The studied bronze contains significant quantities of minor elements like $\mathrm{Pb}$ and $\mathrm{Zn}$ (table 1 ) that may contribute to the overall electrochemical behaviour of bronze in a given medium. Therefore, electrochemical responses of $\mathrm{Cu}, \mathrm{Sn}, \mathrm{Pb}$ and $\mathrm{Zn}$ are also reported, with and without PDTC in $30 \mathrm{~g} \mathrm{~L}^{-1} \mathrm{NaCl}$.

Figures 3 and 4 show polarization curves obtained after one hour immersion for anodic and cathodic scans from corrosion potential ( $\left.\mathrm{E}_{\mathrm{corr}}\right)$.

\subsection{1.a. Electrochemical behavior of bronze, $\mathrm{Cu}, \mathrm{Sn}, \mathrm{Pb}$ and $\mathrm{Zn}$ in $30 \mathrm{~g} \mathrm{~L}^{-1} \mathrm{NaCl}$}

Figure 3a shows that the electrochemical behaviour of bronze seems to be similar to that of copper in $30 \mathrm{~g} \mathrm{~L}^{-1} \mathrm{NaCl}$. Ecorr values are closer since that of bronze is just about $0.05 \mathrm{~V}$ more anodic. The peak observed at $0.022 \mathrm{~V}$ and $0.083 \mathrm{~V}$ for copper and bronze, respectively, can be attributed to $\mathrm{Cu}$ oxidation into $\mathrm{Cu}^{+}$. The subsequent decrease in current is due to $\mathrm{CuCl}$ formation followed by a current increase corresponding to $\mathrm{CuCl}_{2}^{-}$formation [36, 38-40]. As for the cathodic domain, bronze is less reactive than copper as current densities are about one decade lower throughout the -0.3 to $-0.9 \mathrm{~V}$ range, corresponding to oxygen reduction, as reported in literature [41]. The broad cathodic peak located around $-1 \mathrm{~V}$ is due to the reduction of tin species [41] and may also include the reduction of $\mathrm{Cu}_{2} \mathrm{O}[35,36,42]$ formed by hydrolysis of the cuprous corrosion products. 
Tin is the other major element in bronze but its electrochemical behaviour is very different from those of bronze and copper. Firstly, the polarization curve of tin shifts towards more cathodic direction to these two materials (about $0.5 \mathrm{~V}$ ). Its Ecorr value is as cathodic as -0.745 V. Moreover, the cathodic current density increases continuously during the potential sweep, no reduction plateau is observed and the cathodic peak located around $-1 \mathrm{~V}$ is the result of tin species reduction, mainly oxide hydroxide compounds [41]. Furthermore, in contrast to $\mathrm{Cu}$ and bronze, a pseudo anodic plateau is observed until about $-0.41 \mathrm{~V}$ from which a drastic increase in current is noticed indicating a significant tin dissolution.

Lead exhibits a corrosion potential of $-0.555 \mathrm{~V}$ and shows high activity in both cathodic and anodic domain. In both cases, electrochemical activity is likely due to redox reactions of $\mathrm{PbCl}_{2} / \mathrm{Pb}$ couple [43].

As expected, zinc presents the most cathodic corrosion potential $(-1.06 \mathrm{~V})$ and the highest anodic activity. During immersion, $\mathrm{Zn}$ is passivated by formation of $\mathrm{Zn}_{5}(\mathrm{OH})_{8} \mathrm{Cl}_{2} \cdot 2 \mathrm{H}_{2} \mathrm{O}$ $[44,45]$. The cathodic peak present at $-1.3 \mathrm{~V}$ may correspond to reduction of corrosion products $[46,47]$.

\subsection{1.b. Comparison of $10 \mathrm{mM}$ PDTC Effects on bronze and pure metals (Cu, Sn,} $\underline{\mathrm{Zn}, \mathrm{Pb}) \text { in } 30 \mathrm{~g} \mathrm{~L}^{-1} \mathrm{NaCl}}$

Figure $3 \mathrm{~b}$ shows that PDTC effects are more marked on the kinetics of anodic and cathodic reactions on copper in comparison to bronze. However, the current density plateau in the case of bronze is much larger, maybe due to the fact that PDTC interacts not only with copper [35] but probably also with tin or other elements, thereby allowing the formation of a passive film. Interestingly, for tin, PDTC seems to accelerate corrosion process as anodic and cathodic current densities are increased. Clearly, no inhibitive effect of PDTC can be observed on pure tin. 
For zinc, current density values are slightly decreased in presence of $10 \mathrm{mM}$ PDTC showing low efficiency of PDTC towards corrosion protection on zinc.

For bare lead, PDTC decreases significantly the anodic and cathodic current densities a large passivity plateau is observed showing significant interaction between lead and PDTC.

\subsection{1.c. Effects of PDTC concentration on bronze behavior in $30 \mathrm{~g} \mathrm{~L}^{-1} \mathrm{NaCl}$}

Effect of PDTC on bronze behaviour was studied in $30 \mathrm{~g} \mathrm{~L}^{-1} \mathrm{NaCl}$ at $0.1,1$ and $10 \mathrm{mM}$. The polarization curves plotted are shown in figure 4 .

- For $0.1 \mathrm{mM}$, no effect is clearly visible on the anodic side but a small decrease in cathodic current is observed. Cathodic peak at $-1 \mathrm{~V}$ is lower probably due to smaller quantity of corrosion products formed during immersion. The peak at $-0.73 \mathrm{~V}$, that was not observed without PDTC, and may be attributed to reduction of PDTC compounds formed during maintaining at open circuit potential for $1 \mathrm{~h}$, shows some interactions between bronze and PDTC. Clearly, for such a low content, PDTC begins to interact with the bronze surface but its protection remains rather low.

- At $1 \mathrm{mM}$, PDTC exhibits significant effects on both anodic and cathodic kinetic reactions. Anodic dissolution is slowed down in the potential domain ranging from $\mathrm{E}_{\text {corr }}$ to about $0.01 \mathrm{~V}$ and the value of the current density plateau is lower than that obtained for the blank. The dissolution becomes afterwards faster and oxidation of $\mathrm{Cu}$ into $\mathrm{Cu}^{+}$happens at higher potential $(323 \mathrm{mV})$ exhibiting an anodic shift of $0.24 \mathrm{~V}$. On the cathodic branch, the peak at $-1 \mathrm{~V}$ is still present but less intense: adsorption of PDTC on bronze surface during immersion may hinder oxides formation [36] and provides more protection efficiency.

- For a higher PDTC concentration i.e. $10 \mathrm{mM}, \mathrm{E}_{\text {corr }}$ is only slightly more anodic and a low current density plateau is enlarged. This plateau shows that products formed on bronze surface during immersion provide surface protection until about $1 \mathrm{~V}$ from which corrosion starts to take place since reproducible current fluctuations appear. The similarity between the 
current density plateau observed with bronze and lead (figure $3 b$ ) tends to indicate that presence of lead plays an important role in corrosion inhibition of PDTC on bronze in chloride media. It is indeed possible that alloying elements influence on both corrosion mechanisms and adsorption phenomena. The effect on cathodic reactivity is less important and a peak is observed around $-0.66 \mathrm{~V}$ due to reduction of corrosion products formed during immersion. Therefore, PDTC seems to have an important inhibitive effect at $10 \mathrm{mM}$, particularly on anodic behaviour. In the case of pure copper, it has been shown that PDTC adsorbs on the surface to form a $\mathrm{Cu}^{\mathrm{I}}$-PDTC adherent and protective complex [36]. It is very likely that a similar compound is also formed onto bronze. Moreover, results obtained above suggest a strong adsorption of PDTC on lead surface which may also the case even when the amount of $\mathrm{Pb}$ is as low as $1.5 \mathrm{wt} \%$ in a $\mathrm{Cu}-\mathrm{Sn}$ matrix.

To sum up, in $\mathrm{NaCl}$ environment, PDTC seems to accelerate the corrosion of $\mathrm{Sn}$ and shows only a slight inhibitive effect on $\mathrm{Zn}$. In contrast, a significant corrosion protection is observed on $\mathrm{Cu}$ and $\mathrm{Pb}$. The good inhibitive effect of PDTC on bronze in $30 \mathrm{~g} \mathrm{~L}^{-1} \mathrm{NaCl}$ is then most likely due to its interaction with $\mathrm{Cu}$.

\subsubsection{Gravimetric measurements}

Gravimetric measurements were carried out at $\mathrm{OCP}$, in $30 \mathrm{~g} \mathrm{~L}^{-1} \mathrm{NaCl}$ without or with different concentrations of PDTC, with bronze sputtered on gold-coated quartz crystals. Results obtained are shown in figure 5. Two behaviours can be pointed out:

- $\quad$ mass loss when the sample is immersed in the aggressive solution without or with 0.1 mM PDTC.

- significant mass gain when significant concentrations of PDTC are added to the corrosive medium.

These results are quite similar to those obtained in previous studies on pure $\mathrm{Cu}$ [35]. One can note that in absence or presence of $0.1 \mathrm{mM}$ PDTC, a continuous decrease in mass seems to 
take place. However, as shown in the insert, a small mass gain is noticed for the blank during the first hours of immersion. This behaviour was also observed for pure $\mathrm{Cu}$ electrode and was attributed to formation of $\mathrm{Cu}_{2} \mathrm{O}$ and $\mathrm{CuCl}$ layers $[35,48]$. Obviously, other products may also form on the electrode surface as Sn and other elements are present in the deposited layer. Moreover, mass loss $\Delta \mathrm{m}$ is much more important in presence of the lowest quantity of PDTC. This can be explained by the fact that PDTC increases Sn corrosion, as shown by polarization tests results (cf 3.1.1.b.). Besides, in presence of such quantity of PDTC, $\mathrm{Cu}$ dissolution and $\mathrm{CuCl}_{2}-$ formation occur $[35,38,49]$.

For higher PDTC concentrations, a significant mass increase occurs as soon as the immersion, and reaches constant value after a few hours. Mass increase is faster and greater with increasing PDTC concentration. For pure $\mathrm{Cu}$, this behaviour was attributed to the formation of $\mathrm{CuCl}$ film stabilized with PDTC [38]. This might also be valid for bronze with a possible formation of additional films due to the presence of Sn and other elements. It is then difficult to get accurate information about the adsorption mechanism of PDTC from these results, due to complex alloy composition. Besides, working with bronze sample obtained by vapour deposition brings some quantitative differences in comparison to bare bronze as microstructure does not present a dendritic structure (figure 1f) but a homogeneous dispersion of elements within the deposited layer. Nevertheless, experiments presented in this section show an important mass gain for high PDTC concentrations in agreement with polarization results that showed good inhibitive effect for $1 \mathrm{mM}$ and $10 \mathrm{mM}$ PDTC. As for copper, this compound would protect bronze surface by stabilizing surface films.

\subsubsection{EIS measurements}

EIS measurements were carried out, at corrosion potential, at different immersion periods up to 24 hours in $30 \mathrm{~g} \mathrm{~L}^{-1} \mathrm{NaCl}$ without and with PDTC. 
Figure 6 shows the impedance spectra obtained after 24 hours immersion of bronze in test solutions. It can be seen that PDTC effect is significant at 1 and $10 \mathrm{mM}$. For concentration at $0.1 \mathrm{mM}$ PDTC, the insert shows that no improvement in corrosion resistance is achieved compared to the blank solution. This is in agreement with the previous results since at this concentration, PDTC shows no influence on the polarization curve (figure 4) and the results obtained by EQCM (figure 5) show a greater mass loss than that recorded for the blank and which was attributed to the detrimental effect of PDTC on the corrosion of Sn. On the other hand, these spectra are similar to those obtained with $\mathrm{Cu}$ in the presence of PDTC [35] and for a bronze covered by patinas $[10,11]$. They exhibit three time constants, though not clearly seen, three capacitive loops are necessary to simulate the impedance spectra. The three loops can be observed above $10 \mathrm{~Hz}$, in the 0.1 to $1 \mathrm{~Hz}$ region and below $0.1 \mathrm{~Hz}$. Thus, the equivalent circuit of figure 7 was used to fit the experimental data. This circuit consists of: - A high frequency loop $R_{\mathrm{f}}-C_{\mathrm{f}}$ which corresponds to the capacitance and a parallel resistance of the surface film by corrosion products modified by inhibitor. $R_{\mathrm{f}}$ represents the resistance towards the access of ions through the film and the film capacitance $\mathrm{C}_{\mathrm{f}}$ occurs because of the dielectric nature of the film.

- A medium frequency loop $R_{\mathrm{t}}-C_{\mathrm{d}}$ which corresponds to the charge transfer resistance and double layer capacitance that appears at the electrode interface.

- At low frequencies, a process represented by $\mathrm{R}_{\mathrm{F}}-\mathrm{C}_{\mathrm{F}}$ due to faradaic processes of oxidation and reduction dominates the spectrum. $R_{\mathrm{F}}$ is associated with the rate of an oxidation-reduction process that occurs at the electrode and $C_{\mathrm{F}}$ the corresponding pseudo capacitance.

- $n_{\mathrm{f}}, n_{\mathrm{d}}, n_{\mathrm{F}}$ are cole-cole coefficients representing the depressed feature of the capacitive loops in Nyquist diagrams [50,51].

This depressed shape was represented by the following equation identical to the ColeCole frequency dispersion of dielectrics: 
$Z=\frac{R}{1+(\mathrm{j} \cdot \omega \cdot R \cdot C)^{\mathrm{n}}}$

where $\mathrm{n}$ is a fractional number comprised between 0 and 1 . It is similar to the constant phase element (CPE) impedance frequently used nowadays, but unlike CPE the distribution of time constant $\tau=\mathrm{R} \cdot \mathrm{C}$ would be involved in the capacitance as well as in the resistance.

\subsection{3.a. $R_{f}-C_{f}$ couple}

In the blank and $0.1 \mathrm{mM}$ PDTC solutions, figure 8 shows that $\mathrm{R}_{\mathrm{f}}$ and $\mathrm{C}_{\mathrm{f}}$ remain practically identical and change relatively slowly over time. $R_{f}$ values gradually increase from about 2 to $4.5 \Omega \mathrm{cm}^{2}$ up to $12 \mathrm{~h}$ and then remain almost constant.

As for $\mathrm{C}_{\mathrm{f}}$, the values decrease slightly with time from approximately 10 to $3 \mu \mathrm{F} \mathrm{cm} \mathrm{cm}^{-2}$. Note that such values suggest the formation of extremely thin films. The slow decrease of $\mathrm{C}_{\mathrm{f}}$ and increase of $\mathrm{R}_{\mathrm{f}}$ with time suggests a slow film thickening. In contrast, in the presence of 1 and $10 \mathrm{mM}$ PDTC, $\mathrm{C}_{\mathrm{f}}$ takes values near $37 \mathrm{nF} \mathrm{cm}^{-2}$ after 8 hours of exposure following an initial decrease. Here, $\mathrm{C}_{\mathrm{f}}$ appears to be those of thick dielectric films. The corresponding film resistances achieve values of 30 and $150 \mathrm{k} \Omega \mathrm{cm}^{2}$ for 1 and $10 \mathrm{mM}$ PDTC respectively, after long time exposure.

Although $\mathrm{C}_{\mathrm{f}}$ values are almost the same for the films formed in 1 and $10 \mathrm{mM}$ PDTC solutions, the respective values of $R_{f}$ are quite different. This suggests that these films have about the same thickness but the bronze surface coverage and its permeability towards charged species differ significantly giving rise to a large difference in the film resistances.

\subsection{3.b. $R_{t} C_{d}$ couple}

The double layer capacitance and charge transfer resistances (figure 9) exhibit similar behaviour as the blank and $0.1 \mathrm{mM}$ PDTC giving nearly time invariant values of $\mathrm{C}_{\mathrm{d}}(\sim 70$ $\left.\mu \mathrm{F} \mathrm{cm}{ }^{-2}\right)$ and $R_{t}\left(2-3 \mathrm{k} \Omega \mathrm{cm}^{2}\right)$, whereas a substantial decrease in $\mathrm{C}_{\mathrm{d}}$ and increase in $\mathrm{R}_{\mathrm{t}}$ occur in 
the 1 and $10 \mathrm{mM}$ PDTC during the first 8-10 hours of exposure. Significantly, after 10 hours the $\mathrm{C}_{\mathrm{d}}$ values for $1 \mathrm{mM}$ exceeds that for $10 \mathrm{mM}$ concentration by about a factor of 3.5 while the $\mathrm{R}_{\mathrm{t}}$ for $10 \mathrm{mM}$ is about 3 times greater than that for $1 \mathrm{mM}$ concentration. This behaviour could be explained by an increased coverage by a thick dielectric film in going from 1 to 10 mM PDTC solutions. Once again, regarding PDTC effect at $0.1 \mathrm{mM}$ level, no discernible influence on the bronze surface is observed as compared to the blank. The product $\mathrm{R}_{\mathrm{t}} \cdot \mathrm{C}_{\mathrm{d}}$ is essentially similar for all cases examined here, i.e. the reactivity of bronze for a given bare surface does not change significantly. The effect of PDTC is therefore due to the reinforcing of barrier properties of surface layer.

\subsection{3.c. $R_{F}-C_{F}$ couple}

This couple is mainly attributed to the kinetics of the reversible redox process taking place on $\mathrm{Cu} / \mathrm{Cu}^{+}$zone $[10,35]$. The faradaic resistance $\mathrm{R}_{F}$ and capacitance $\mathrm{C}_{F}$ change with respect to immersion time are presented in figure $10 . \mathrm{R}_{\mathrm{F}}$ values obtained in 1 and $10 \mathrm{mM}$ PDTC solutions increase to the steady-state values of $1 \mathrm{M} \Omega \mathrm{cm}^{2}$ after 8-10 hours exposure. Bronze, in the blank and $0.1 \mathrm{mM}$ environments give similar performance but rather achieving much lower steady state $\mathrm{R}_{\mathrm{F}}$ value around $10 \mathrm{k} \Omega \mathrm{cm}^{2}$ after 10 hours of immersion. It should be noted that the $R_{F}$ value was evaluated with a marked extrapolation of the lowest frequency loop, thus its reliability is poor. Consequently, the comparison is qualitative. $\mathrm{C}_{\mathrm{F}}$ values in all media generally decrease with time. For the blank and $0.1 \mathrm{mM}$ PDTC, the values obtained are at least an order of magnitude higher compared to those for the bronze in 1 and $10 \mathrm{mM}$ PDTC solutions. In 0.1 mM PDTC environment, $\mathrm{C}_{\mathrm{F}}$ remains somewhat higher than that observed for the blank. This suggests that for the bronze in the small quantity of PDTC some electrochemical reaction occurs at a slightly higher rate. In higher concentrated PDTC solutions, $\mathrm{C}_{\mathrm{F}}$ decreases during immersion and the values obtained in $10 \mathrm{mM}$ are slightly higher than those corresponding to $1 \mathrm{mM}$ PDTC. There are clearly two competing processes 
occurring here. On one hand as the PDTC/corrosion products film forms, the fractional area of active surface decreases. In fact at $1 \mathrm{mM}$ and above, the surface is nearly completely covered by the thick dielectric inhibitor/corrosion products film. On the other hand, electrochemical (Faradaic) processes are accelerated by increasing concentration of inhibitor which would generally give rise to a higher observed pseudo-capacitance.

\subsection{3.d. Polarization resistance $R_{p}$ and surface coverage ratio $\theta$}

Figure 11a shows the variation of the polarization resistance $\mathrm{R}_{\mathrm{p}}$ during the immersion period of the bronze electrode in $30 \mathrm{~g} \mathrm{~L}^{-1} \mathrm{NaCl}$ without and with different concentrations of PDTC. Since the resistance of the film $\mathrm{R}_{\mathrm{f}}$ is a non-faradic quantity, the polarization resistance $\mathrm{R}_{\mathrm{p}}$ is given by the sum of the charge transfer resistance $R_{t}$ and the faradic resistance $R_{F}$ as:

$\mathrm{R}_{\mathrm{p}}=\mathrm{R}_{\mathrm{t}}+\mathrm{R}_{\mathrm{F}}$

When redox processes are involved, $R_{p}$ is better correlated with the corrosion rate than $R_{t}[10$, 52].

As expected, $R_{p}$ increases with immersion time and is significant for 1 and $10 \mathrm{mM}$ PDTC. In the solution containing $0.1 \mathrm{mM}, \mathrm{R}_{\mathrm{p}}$ reaches values close to $10 \mathrm{k} \Omega \mathrm{cm}^{2}$ and remains similar to those obtained for the blank, which is in agreement with the above results. In contrast, for 1 and $10 \mathrm{mM}$, the inhibitive effect of PDTC is important, mainly at $10 \mathrm{mM}$ during the first 8 hours of immersion. Beyond this time period, the values of $\mathrm{R}_{\mathrm{p}}$ are close for both concentrations and the effect of the PDTC is more significant since values of $R_{p}$ of the order of $1 \mathrm{M} \Omega \mathrm{cm}^{2}$ are obtained. Thus, the inhibitive effect is estimated to be around $99 \%$.

From $R_{p}$ values, the fractional surface coverage $\theta$ could be calculated since:

$$
\theta=1-\frac{R_{p}^{0}}{R_{p}}
$$


where $R_{p}^{0}$ and $\mathrm{R}_{\mathrm{p}}$ denote the polarization resistances in absence and in presence of PDTC, respectively.

Figure $11 \mathrm{~b}$ shows the undesirable effect of PDTC on bronze at $0.1 \mathrm{mM}$ during the first hours of immersion. Moreover, the values of $\theta$ are fairly low and scattered suggesting the formation of less adherent film and therefore less protective, which corroborates the voltammetric results. In contrast and as expected, the presence of 1 or $10 \mathrm{mM}$ PDTC allows the surface coverage ratio of the bronze close to 1 , which is in agreement with the formation of an insulating and protective barrier film. Hence with sufficient concentration, the surface is nearly completely covered. However, residual defects are more readily depolarized by reaction with the inhibitor according to $\mathrm{C}_{\mathrm{F}}$ change.

\subsection{3.e. Film thickness $\delta$}

The film capacitance $\mathrm{C}_{\mathrm{f}}$ of the oxide or oxide/inhibitor film can be also directly determined by considering a complex capacitance $\mathrm{C}(\omega)$ corrected from the electrolyte resistance $\mathrm{R}_{\mathrm{e}}$ as:

$$
C(\omega)=\frac{1}{j \cdot\left(Z(\omega)-R_{e}\right)}
$$

The Cole-Cole representations of the complex capacitance in semi-log coordinates corresponding to experimental EIS spectra give a curve similar to that shown in Figure 12a. It is then easy to extract the high frequency capacitance $C_{\infty}$ of the surface film without reference to the nature of the time constant distribution within the film [53]. $C_{\infty}$ values are found to be very close the $\mathrm{C}_{\mathrm{f}}$ ones as deduced from the fitting of EIS data. Thus, assuming a permittivity $\varepsilon$ $=10$ for the oxide films formed in the blank and $0.1 \mathrm{mM}$ PDTC and $\varepsilon=4$ for those formed in the solutions containing 1 and $10 \mathrm{mM}$ PDTC, the thickness of the surface layer can be easily obtained, if the planar condenser model is assumed, using the following equation: 


$$
\delta=\frac{\varepsilon \cdot \varepsilon_{0}}{C_{\infty}}
$$

In the case of films formed on the electrode surface in the blank and the solution containing $0.1 \mathrm{mM}$ PDTC, figure $12 \mathrm{~b}$ shows that the thickness values are comparable and ranging from about 1 to $2.6 \mathrm{~nm}$. It should be noted that the gravimetric measurements showed dissolution of the bronze at the very beginning of the electrode immersion in $0.1 \mathrm{mM}$ PDTC solution and that the loss of mass recorded is much significant than for the blank. In fact, during this stage, the accumulation of the corrosion products is taking place together with the substrate dissolution. A corrosion products film is formed in the solution containing $0.1 \mathrm{mM}$ PDTC even if the dissolution prevails due to the aggressiveness of PDTC to Sn (cf. polarization section). As stated above, the film formed in the blank may consist of $\mathrm{Cu}_{2} \mathrm{O}$ and $\mathrm{CuCl}[35$, 48]. Regarding the film formed in $0.1 \mathrm{mM}$ PDTC, in addition to the corrosion products of bronze with PDTC, these same species may also be present in the film.

For higher concentrations of PDTC the films formed are thicker and reach, after 24hours of immersion, 103 and $123 \mathrm{~nm}$ in the solutions containing 1 and $10 \mathrm{mM}$ PDTC respectively. It can be observed that the increase in thickness is faster and significant even after 1 hour of immersion in the solution containing $10 \mathrm{mM}$ PDTC. In both cases, the increase in thickness is slowed down after 8 hours of immersion and a nearly steady-state value is observed. For instance, for $10 \mathrm{mM}$, the thickness increases from 113 to $123 \mathrm{~nm}$ from 8 to 24 hours immersion time. On the other hand, it can be noted that for these two high concentrations of PDTC, the variation of the thickness $\delta$ during the immersion period is comparable to that of the film resistance $\mathrm{R}_{\mathrm{f}}$ (cf. figure $8 \mathrm{a}$ ). It can then be assumed that in presence of PDTC, the film resistance depends essentially on its thickness.

It is worth remarking that the low frequency behaviour of impedance spectra is markedly influenced by the bulk concentration of PDTC. Namely below $1 \mathrm{~Hz}$, Nyquist diagrams are 
characterized by a straight line, with a slope close to 1 for the $1 \mathrm{mM}$ concentration and roughly a half value for the $10 \mathrm{mM}$ one. From the electrical model used for impedance analysis, it was shown that both the surface coverage, the thickness of the PDTC coating, the transfer resistance at the metal/electrolyte interface increase with an increase in the bulk concentration of inhibitor. In this approach, the more direct effect of the film is to promote a series resistance $\mathrm{R}_{\mathrm{f}}$ which reflects in the diameter of the capacitive loop at high frequencies and then does not influence the low frequency behaviour. It is no more the case if we consider that the surface film is both resistive and porous. Models for porous film electrodes are well documented in literature [54]. Such a picture of a porous film electrode is able to give the low frequency behaviour on a physical basis. When the surface film is thick (model I in [54] for $10 \mathrm{mM}$ PDTC), the impedance response may be simulated as that of a porous film electrode coupled with the geometric resistance and capacitance of the film. In other cases (model II in [54] for cases of $1 \mathrm{mM}$ or less), the surface coverage is not full. Two contributions in parallel have to be considered, (i) a porous film impedance as above where the metal substrate is coated by the film, (ii) an interfacial impedance with a Warburg term for the bare electrode surface. With model II, a slope greater than the unity would originate from the diffusion of corrosion products in the solution corresponding to the fraction of the electrode surface not protected. Model I is able to account for a slope of lower value considering a fully covered metal surface and a transport of corrosion products via the porosity of the organic film. The above description suggests that the impedance behaviour at low frequencies provides a complementary criterion for judging the more or less blocking character of the organic coating.

\subsubsection{Inhibitive effect of PDTC evaluated with various methods}

Different methods were used to characterize the electrochemical behaviour of bronze electrode in $30 \mathrm{~g} \mathrm{~L}^{-1} \mathrm{NaCl}$ solution in presence of various concentrations of PDTC. From 
figures 4, 5 and 6 it can be seen that the results obtained by these methods all show that no inhibitive effect of PDTC is distinctly observed for $0.1 \mathrm{mM}$. However, for higher concentrations ( 1 and $10 \mathrm{mM})$ a significant inhibitive effect is obtained.

In general, corrosion current densities $\left(\mathrm{j}_{\text {corr }}\right)$ evaluated from these methods allow the estimation of the corrosion rate and therefore the efficiency of the PDTC. Nevertheless, because of the complex nature of the processes taking place at the interface bronze / PDTC + $30 \mathrm{~g} \mathrm{~L}^{-1} \mathrm{NaCl}$, the results obtained from polarization curves only allow a qualitative study of the electrochemical behaviour of the electrode at different concentrations of PDTC. As for EQCM results, the rate of mass change $\Delta \mathrm{m} / \Delta \mathrm{t}$ may directly be associated with the corrosion rate jcorr determined by applying Faraday's law. Nevertheless, this evaluation can be difficult because of the complex structure of the electrode and also the competition between the electrode dissolution and the formation of corrosion products. For the blank test solution and low PDTC concentrations, the electrode dissolves as cuprous ions and $\mathrm{CuCl}_{2}{ }^{-}$formation [35]. $\mathrm{Cu}_{2} \mathrm{O}$ and $\mathrm{CuCl}$ may also form upon the electrode surface $[35,48]$. For higher concentrations, an adsorbed PDTC film forms on the electrode. It is important to emphasize that the estimation of $\mathrm{j}$ corr by $\Delta \mathrm{m}(\mathrm{t})$ curves postulates that the amount of the surface species reached its steady state value. Besides the accumulation of corrosion products takes place together with electrode dissolution. Therefore the corrosion current density evaluated from the rate of mass change should be underestimated [35]. In contrast, EIS measurements supply consistent data. In EIS method, the perturbing signal is sufficiently small so that the electrode remains essentially at its open circuit conditions and the results may be relevant even for complex processes. Thereby, the values obtained for the charge transfer and the polarization resistances increased substantially above $1 \mathrm{mM}$ PDTC suggesting a significant inhibitive effect and an important surface coverage ratio which was close to 1.

\subsection{Surface analyses}




\subsubsection{SEM and EDS analyses}

SEM observations (figure 13) and EDX analyses (figure 14 and table 3) were carried out on bronze surface after $24 \mathrm{~h}$ immersion in $30 \mathrm{~g} \mathrm{~L}^{-1} \mathrm{NaCl}$, without and with different PDTC concentrations. EDX spectra obtained for $0.1 \mathrm{mM}$ and $1 \mathrm{mM}$ (not shown) are comparable to those of the blank and $10 \mathrm{mM}$ PDTC, respectively. This confirms that the films developed on bronze in the blank and $0.1 \mathrm{mM}$ PDTC solutions are composed of the same elements and have similar thicknesses according to the EIS.

These observations and analyses show formation of surface films whose amount, aspect and microstructure depend on the presence or absence of PDTC in solution. Indeed, without PDTC, an oxides film is formed on bronze surface as it can be seen on figure 13a, whereas figure $13 \mathrm{~b}$ clearly shows a non-adherent and inhomogeneous film of corrosion products on the surface when $0.1 \mathrm{mM}$ PDTC is present in the medium. This layer is obviously different in appearance from that formed in the blank solution even if the same spectra are obtained. In fact, with 0.1 mM PDTC, oxides and PDTC compounds form. Sulphur peak does not appear in the analysis, probably due to the low PDTC concentration.

For higher PDTC concentrations, SEM images (figures 13c and 13d) show surfaces covered with a film of organic appearance. Indeed, EDX spectrum (figure 14 and table 3 ) shows the presence of sulphur peak proving the presence of PDTC in the surface layer. Moreover, one can note the very low quantity of oxygen within the films suggesting that PDTC adsorption is fast and prevents oxides formation. Similar results were observed in the case of pure $\mathrm{Cu}$ [36]. It can be concluded that a barrier film, resulting from PDTC adsorption, is formed on bronze surface in presence of $1 \mathrm{mM}$ and $10 \mathrm{mM}$ PDTC. This is in agreement with electrochemical results which have furthermore shown, in potentiodynamic polarization section, that an insulating film forms on $\mathrm{Cu}$ and not on $\mathrm{Sn}$ (cf $\S 3.1 .1 . \mathrm{b}$ and figure $3 \mathrm{~b}$ ).

\subsubsection{Raman micro-spectroscopy analyses}


Raman micro-spectroscopy was used to characterize the bronze surface after $24 \mathrm{~h}$ immersion in $30 \mathrm{~g} \mathrm{~L}^{-1} \mathrm{NaCl}$ with and without PDTC. The obtained spectra are presented on figure 15. It should be pointed out that for $1 \mathrm{mM}$ PDTC, the obtained spectrum (not shown) is similar to that recorded for $10 \mathrm{mM}$ but with lower intensities suggesting the formation of the same surface film under both conditions.

When the film is formed without or with $0.1 \mathrm{mM}$ PDTC, Raman spectra are similar and show a doublet at 500 and $600 \mathrm{~cm}^{-1}$ assigned to $\mathrm{Cu}_{2} \mathrm{O}$ layer formation [55], which corroborates EDX results.

In the presence of $10 \mathrm{mM}$ PDTC, the spectrum obtained is quite different from the previous ones, but it is similar to that obtained on pure $\mathrm{Cu}$ in the same conditions [36]. It may be then concluded that the same species form on the bronze surface and the spectrum highlights only the response of $\mathrm{Cu}$ contained in the bronze. Thus, as for pure copper, the formed layer does not contain $\mathrm{Cu}_{2} \mathrm{O}$ oxide as the corresponding band disappears. Besides, the band at $450 \mathrm{~cm}^{-}$

${ }^{1}$ attributed to S-C-S vibration [36] and those at 290 and $330 \mathrm{~cm}^{-1}$ attributed to $\mathrm{Cu}-\mathrm{S}$ stretching [34] confirm the presence of a PDTC layer on the bronze surface. It can be then assumed that PDTC adsorbs on the bronze surface, especially at $\mathrm{Cu}$ sites, by binding with its $\mathrm{S}$ atoms to form $\mathrm{Cu}^{\mathrm{I}}$-PDTC complex [36]. Thus, Raman experiments show that for $0.1 \mathrm{mM}$ PDTC only oxides form on bronze but for $1 \mathrm{mM}$ and $10 \mathrm{mM}$ PDTC, the molecule is adsorbed on the surface via $\mathrm{Cu}-\mathrm{S}$ bonds. However, polarization tests showed that PDTC may interact also with $\mathrm{Pb}$ but its response is probably too low to be detected in the Raman spectrum which is only sensitive to the interaction of $\mathrm{Cu}$ with PDTC.

\subsubsection{XPS analysis}

XPS spectra were collected to analyse films formed on bronze surface after 24 hours immersion in $30 \mathrm{~g} \mathrm{~L}^{-1} \mathrm{NaCl}$ with and without $10 \mathrm{mM}$ PDTC. Survey spectra are presented on figure 16. For the blank, the spectrum shows the presence of $\mathrm{Cu}, \mathrm{Sn}, \mathrm{Pb}, \mathrm{O}$ and $\mathrm{C}$ peaks. 
Bronze surface seems oxidized without PDTC which is in agreement with EDX and Raman results. Carbon presence is due to surface contamination by organic species. In presence of PDTC, signals of $\mathrm{N}, \mathrm{C}$ and $\mathrm{S}$ elements are visible in the spectrum indicating PDTC adsorption on the electrode surface. C1s peak is more intense than the one observed for the blank due to carbons contained in PDTC. On the other hand, the absence of peaks of $\mathrm{Pb}$ and $\mathrm{Sn}$ confirm the formation of a coating of at least $10 \mathrm{~nm}$ thickness corresponding to the depth limit of the analysis, which is in agreement with EIS measurements.

One can also note that, even though the films are formed in chloride medium, no $\mathrm{Cl}$ peak in the region of $200 \mathrm{eV}$ appeared either in the presence or in the absence of PDTC. The same fact was observed on $\mathrm{Cu}$ with PDTC [36] and other organic molecules [14, 56-58].

Figure 17 shows the $\mathrm{Cu} 2 \mathrm{p}$ and $\mathrm{Cu} \mathrm{LMM}$ peaks obtained from the films formed in the absence and presence of PDTC. For both films, one can note the absence of satellite peaks at energies beyond $\mathrm{Cu} 2 \mathrm{p}_{3 / 2}$ and also a kinetic energy peak of $\mathrm{Cu} \mathrm{LMM}$ of about $916 \mathrm{eV}$. This means that $\mathrm{Cu}$ is cuprous state. This is in agreement with results obtained for pure $\mathrm{Cu}$ with PDTC [36] and with other molecules [59-61]. This result shows that $\mathrm{Cu}_{2} \mathrm{O}$ forms on the blank, and that $\mathrm{Cu}^{\mathrm{I}}-\mathrm{S}$ bonds and $\mathrm{Cu}_{2} \mathrm{O}$ form in the presence of PDTC. One also notes that the $\mathrm{Cu}_{2} \mathrm{P}_{1 / 2}$ peak is slightly shifted toward higher energies in the presence of PDTC suggesting the presence of bonds between $\mathrm{Cu}^{\mathrm{I}}$ and $\mathrm{S}$ [62], or that the PDTC is adsorbed on a very thin film of $\mathrm{Cu}_{2} \mathrm{O}$ [63]. The O1s peak (figure 18) present at $530.7 \mathrm{eV}$ in the case of the blank confirms the presence of $\mathrm{Cu}_{2} \mathrm{O}$ on the bronze surface $[64,65]$. In presence of PDTC, this peak energy is higher probably due to the adsorption of few $\mathrm{H}_{2} \mathrm{O}$ molecules [65] and its intensity is smaller because of the small quantity of oxides formed [36]. Indeed, on Cu LMM peak, a shoulder is observed around $918.3 \mathrm{eV}$ corresponding to $\mathrm{Cu}^{0}$ meaning that the formed oxide layer is very thin. 
In the literature, binding energy of $\mathrm{N} 1 \mathrm{~s}$ is $398 \mathrm{eV}[66,67]$. In the film formed on bronze, in presence of PDTC (figure 18), this peak appears at $399.9 \mathrm{eV}$ suggesting that nitrogen atoms of PDTC are implicated in the formation of a complex between bronze and the ligand.

The spectrum of S2p (figure 18) exhibits two peaks at $162.2 \mathrm{eV}$, and $163.3 \mathrm{eV}$ due to $\mathrm{S} 2 \mathrm{p}_{3 / 2}$ and $\mathrm{S} 2 \mathrm{p}_{1 / 2}$ respectively. These energies are separated by $1.1 \mathrm{eV}$ and are lower in intensity as compared to the normal values [66]. This may result from the formation of an adsorbed film of PDTC probably through a thiolate group $[19,68]$.

\section{Conclusion}

The present study, based on the combination of a number of electrochemical and spectroscopic techniques, was devoted to investigate the ability of ammonium pyrrolidinedithiocarbamate (PDTC) to protect a bronze substrate (copper matrix with $\mathrm{Sn}, \mathrm{Pb}$ and $\mathrm{Zn}$ ) against corrosion in a neutral chloride environment. Concerning effects of $10 \mathrm{mM}$ PDTC on pure metals, a good corrosion inhibition was obtained for $\mathrm{Cu}$ and much less for $\mathrm{Zn}$ and no corrosion inhibition enhancement was found for Sn. For the bronze substrate, PDTC was shown to interact via a fast preferential adsorption on copper and lead sites in competition with the corrosion process. This competition was found to depend on the PDTC concentration, in the range $0.1 \mathrm{mM}$ to $10 \mathrm{mM}$, with the result that below $1 \mathrm{mM}$ PDTC concentration no protective effect was observed. On the contrary, above $1 \mathrm{mM}$, PDTC was proved to be very efficient for preventing bronze corrosion. Indeed, the transfer resistance values obtained from EIS results increased significantly beyond 1mM. Moreover, the surface coverage ratio of the bronze was close to 1 . Spectroscopic analyses confirm the film to be grafted to the bronze substrate covalently through the formation of a $\mathrm{Cu}^{\mathrm{I}}-\mathrm{PDTC}$ complex and to be essentially composed with organic molecules of PDTC. Other organic inhibitors will be studied and compared to PDTC regarding corrosion protection efficiency.

\section{Acknowledgements}


The University of El Jadida who authorized Pr. W. Qafsaoui to attend the LISE before the end of University year is gratefully acknowledged.

The authors thank F. Pillier for SEM analyses and F. Billon for PVD coatings. 


\section{References}

[1] C.K. Hu, B. Luther, F.B. Kaufuman, J. Hummel, C. Uzoh, D.J. Pearson, Copper interconnection integration and reliability, Thin Solid Films 262 (1995) 84-92.

[2] K.L. Lee, C.K. Hu, K.N. Tu, In situ scanning electron microscope comparison studies on electromigration of $\mathrm{Cu}$ and $\mathrm{Cu}(\mathrm{Sn})$ alloys for advanced chip interconnects, J. Appl. Phys. 78 (1995) 4428-4437.

[3] D. Padhi, S. Gandikota, H.B. Nguyen, C. McGuirk, S. Ramanathan, J. Yahalom, G. Dixit, Electrodeposition of copper-tin alloy thin films for microelectronic applications, Electrochim. Acta 48 (2003) 935-943.

[4] W. Pu, X. He, J. Ren, C. Wan, C. Jiang, Electrodeposition of Sn-Cu alloy anodes for lithium batteries, Electrochim. Acta 50 (2005) 4140-4145.

[5] J.S. Thorne, J.R. Dahn, M.N. Obrovac, R.A. Dunlap, A comparison of sputtered and mechanically milled Cu6Sn5 + C materials for Li-ion battery negative electrodes, J. Power Sources 216 (2012)139-144.

[6] L. Robbiola, J-M. Blengino, C. Fiaud, Morphology and mechanisms of formation of natural patinas on archaeological Cu-Sn alloys, Corros. Sci. 40 (1998) 2083-2111.

[7] L. Robbiola, C. Fiaud, Apport de l'analyse statistique des produits de corrosion à la compréhension des processus de dégradation des bronzes archéologiques, Revue d'archéométrie 16 (1992) 109-119.

[8] M. Aucouturier, M. Keddam, L. Robbiola, H. Takenouti, Les patines des alliages de cuivre : processus naturel ou œuvre de l'homme ? Techne 18 (2003) 86-94.

[9] A. Dermaj, N. Hajjaji, S. Joiret, K. Rahmouni, A. Srhiri, H. Takenouti, V. Vivier, Electrochemical and spectroscopic evidences of corrosion inhibition of bronze by a triazole derivative, Electrochim. Acta 52 (2007) 4654-4662. 
[10] K. Marušić, H. Otmačić-Ćurković, H. Takenouti, Inhibiting effect of 4-methyl-1-ptolylimidazole to the corrosion of bronze patinated in sulphate medium, Electrochim. Acta 56 (2011) 7491-7502.

[11] K. Marušić, H. Otmačić-Ćurković, S, Horvat-Kurbegovic, H. Takenouti, E. StupnišekLisac, Comparative studies of chemical and electrochemical preparation of artificial bronze patinas and their protection by corrosion inhibitor, Electrochim. Acta, 54 (2009) 7106-7113. [12] M.M. Antonijevic, M.B. Petrovic, Copper Corrosion Inhibitors. A review, Int. J. Electrochem. Sci. 3 (2008) 1-28.

[13] O. Blajiev, A. Hubin, Inhibition of copper corrosion in chloride solutions by aminomercapto-thiadiazol and methyl-mercapto-thiadiazol: an impedance spectroscopy and a quantum-chemical investigation, Electrochim. Acta 49 (2004) 2761-2770.

[14] M. Finsgar, 2-Mercaptobenzimidazole as a copper corrosion inhibitor: Part II. Surface analysis using X-ray photoelectron spectroscopy, Corros. Sci. 72 (2013) 90-98.

[15] M. Finsgar, D.K. Merl, An electrochemical, long-term immersion, and XPS study of 2mercaptobenzothiazole as a copper corrosion inhibitor in chloride solution, Corros. Sci. 83 (2014) 164-175.

[16] M. Ohsawa, W. Suëtaka, Spectro-electrochemical studies of the corrosion inhibition of copper by mercaptobenzothiazole, Corros. Sci. 19 (1979) 709-722.

[17] A.B. Patel, N.K. Patel, J.C. Vora, 2-mercaptothiazoline as corrosion inhibitor for copper in acidic media, Corros. Sci. 14 (1974) 233-237.

[18] C.W. Yan, H.C. Lin, C.N. Cao, Investigation of inhibition of 2-mercaptobenzoxazole for copper corrosion, Electrochim. Acta 45 (2000) 2815-2821.

[19] B.V. Appa Rao, Md. Yakub Iqbal, B. Sreedhar, Self-assembled monolayer of 2(octadecylthio)benzothiazole for corrosion protection of copper, Corros. Sci. 51 (2009) 14411452. 
[20] W. Chen, S. Hong, H.B. Li, H.Q. Luo, M. Li, N.B. Li, Protection of copper corrosion in 0.5 M NaCl solution by modification of 5-mercapto-3-phenyl-1,3,4-thiadiazole-2-thione potassium self-assembled monolayer, Corros. Sci. 61 (2012) 53-62.

[21] K. Aramaki, T. Kiuchi, T. Sumiyoshi, H. Nishishara, Surface enhanced Raman scattering and impedance studies on the inhibition of copper corrosion in sulphate solutions by 5 substituted benzotriazoles, Corros. Sci. 32 (1991) 593-607.

[22] G. Xue, J. Ding, P. Lu, J. Dong, SERS, XPS, and electroanalytical studies of the chemisorption of benzotriazole on a freshly etched surface and an oxidized surface of copper, J. Phys. Chem. 95 (1991) 7380-7384.

[23] J. Bukowska, A. Kudelski, K. Jackowska, The use of Surface Enhanced Raman Scattering (SERS) to probe the interaction of imidazole with the silver electrode surface, J.Electroanal. Chem. 309 (1991) 251-261.

[24] R. Yonda, H. Nishishara, K. Aramaki, A SERS study on inhibition mechanisms of benzotriazole and its derivatives for copper corrosion in sulphate solutions, Corros. Sci. 28 (1988) 87-96.

[25] D. Tromans, R. Sun, Anodic Polarization Behavior of Copper in Aqueous Chloride/Benzotriazole Solutions, J. Electrochem. Soc. 138 (1991) 3235-3244.

[26] M. Finsgar, I. Milosev, Inhibition of copper corrosion by 1,2,3-benzotriazole: A review, Corros. Sci. 52 (2010) 2737-2749.

[27] G. Tansug, T. Tüken, E.S. Giray, G. Fındıkkıran, G. Sıgırcık, O. Demirkol, M. Erbil, A new corrosion inhibitor for copper protection,Corros. Sci. 84 (2014) 21-29.

[28] L. Ying, F. Haitao, Z. Yifan, W. Wuji, Study on the inhibiting behavior of AMT on bronze in 5\% citric acid solution, J. Mater. Sci. 38 (2003) 407-411.

[29] E-S.M. Sherif, Effects of 2-amino-5-(ethylthio)-1,3,4-thiadiazole on copper corrosion as a corrosion inhibitor in 3\% NaCl solutions, Appl. Surf. Sci. 252 (2006) 8615-8623. 
[30] E.M. Sherif, S-M. Park, Effects of 2-amino-5-ethylthio-1,3,4-thiadiazole on copper corrosion as a corrosion inhibitor in aerated acidic pickling solutions, Electrochim. Acta 51 (2006) 6556-6562.

[31] L. Valek, S. Martinez, Copper corrosion inhibition by Azadirachtaindica leaves extract in 0.5 M sulphuric acid, Mater. Lett. 61 (2007) 148-151.

[32] J. Chen, C. Du, J. Kang, J. Wang, $\mathrm{Cu}^{2+}$ is required for pyrrolidinedithiocarbamate to inhibit histone acetylation and induce human leukemia cell apoptosis,Chemi-Biol. Inter. 171 (2008) 26-36.

[33] A.E. Al-Rawajfeh, E.M. Al-Shamaileh, Inhibition of corrosion in steel water pipes by ammonium pyrrolidinedithiocarbamate (APDTC),Desalination 206 (2007) 169-178. [34] Q.-Q. Liao, Z.-W. Yue, D. Yang, Z.-H. Wang, Z.-H. Li, H.-H. Ge, Y.-J. Li, Selfassembled monolayer of ammonium pyrrolidinedithiocarbamate on copper detected using electrochemical methods, surface enhanced Raman scattering and quantum chemistry calculations, Thin Solid Films 519 (2011) 6492-6498. [35] W. Qafsaoui, M.W. Kendig, H. Perrot, H. Takenouti, Coupling of electrochemical techniques to study copper corrosion inhibition in $0.5 \mathrm{~mol} \mathrm{~L}^{-1} \mathrm{NaCl}$ by 1-pyrrolidine dithiocarbamate, Electrochim. Acta 87 (2013) 348-360.

[36] W. Qafsaoui, M.W. Kendig, S. Joiret, H. Perrot, H. Takenouti, Ammonium pyrrolidinedithiocarbamate adsorption on copper surface in neutral chloride media, Corros. Sci. 106 (2016) 96-107.

[37] W. Qafsaoui, M.W. Kendig, H. Perrot, H. Takenouti, Effect of 1-pyrrolidine dithiocarbamate on the galvanic coupling resistance of intermetallics - Aluminum matrix during corrosion of AA 2024-T3 in a dilute NaCl, Corros. Sci. 92 (2015) 245-255.

[38] H.P. Lee, K. Nobe, Kinetics and mechanisms of $\mathrm{Cu}$ electrodissolution in chloride media, J. Electrochem. Soc. 133 (1986) 2035-2043. 
[39] G. Kear, B.D. Barker, F.C. Walsh, Electrochemical corrosion of unalloyed copper in chloride media-a critical review, Corros. Sci. 46 (2004) 109-135.

[40] A. Shaban, E. Kálmán, J. Telegdi, An investigation of copper corrosion inhibition in chloride solutions by benzo-hydroxamic acids, Electrochim. Acta 43 (1998) 159-163.

[41] N. Souissi, E. Sidot, L. Bousselmi,E. Triki, L. Robbiola, Corrosion behaviour of Cu10Sn bronze in aerated $\mathrm{NaCl}$ aqueous media - Electrochemical investigation, Corros. Sci. 49 (2007) 3333-3347.

[42] W. Qafsaoui, M.W. Kendig, H. Perrot, H. Takenouti, Corrosion Inhibition of Copper by Selected Thiol Compounds, ECS Transactions, 13 (27) (2008) 123-132.

[43] R. G. Barradas, K. Belinko, J. Ambrose, Electrochemical Behavior of the Lead Electrode in HClandNaCl Aqueous Electrolytes, Can. J. Chem. 53 (1975) 389-406.

[44] M. Mouanga, P. Berçot, J.Y. Rauch, Comparison of corrosion behaviour of zinc in $\mathrm{NaCl}$ and in $\mathrm{NaOH}$ solutions. Part I: Corrosion layer characterization, Corrosion Science 52 (2010) 3984-3992.

[45] T.H. Muster, I.S. Cole, The protective nature of passivation films on zinc: surface charge, Corrosion Science 46 (2004) 2319-2335.

[46] H.J. Flitt, D.P. Schweinsberg, Synthesis, matching and deconstruction of polarization curves for the active corrosion of zinc in aerated near-neutral $\mathrm{NaCl}$

solutions, Corrosion Science 52 (2010) 1905-1914.

[47] F. Suedile, F. Robert, C. Roos, M. Lebrini, Corrosion inhibition of zinc by Mansoaalliacea plant extract in sodium chloride media: Extraction, Characterization and Electrochemical Studies, ElectrochimicaActa 133 (2014) 631-638.

[48] K. Rahmouni, M. Keddam, A. Srhiri, H. Takenouti, Corrosion of copper in 3\% $\mathrm{NaCl}$ solution polluted by sulphide ions, Corrosion Science 47 (2005) 3249-3266. 
[49] C. Deslouis, B. Tribollet, G. Mengoli and M.M. Musiani, Electrochemical behaviour of copper in neutral aerated chloride solution. II. Impedance investigation, J. Appl. Electrochem. 18 (1988) 384-393.

[50] E. Barsoukov, J.R. Macdonald, Impedance spectroscopy, Theory, Experiment, and Applications, John Wiley and Sons, New York, NY, 2005, pp 16-20.

[51] K.S. Cole, R.H. Cole, Dispersion and absorption in dielectrics- I Alternating current characteristics, Journal of Chemical Physics 9 (1941) 341-351.

[52] I. Epelboin, C. Gabrielli, M. Keddam, H. Takenouti, A-C impedance measurements applied to corrosion studies and corrosion rate determination, in "Electrochemical Corrosion Testing“,F. Mansfeld, U. Bertocci editors, STP 727,150-192. American Society for Testing and Materials, Philadelphia, Pa (1981).

[53] M. Benoit, C. Bataillon, B. Gwinner, F. Miserque, M. E. Orazem, C. M. SánchezSánchez, B. Tribollet, V. Vivier, Comparison of different methods for measuring the passive film thickness on metals, Electrochim. Acta 201 (2016) 340-347.

[54] J. Bisquert, Influence of the boundaries in the impedance of porous film electrodes, Phys. Chem. Chem. Phys. 2 (2000), 4185-4192.

[55] M.C. Bernard, S. Joiret, Understanding corrosion of ancient metals for the conservation of cultural heritage, ElectrochimicaActa, 54 (2009) 5199-5205.

[56] M. Finšgar, EQCM and XPS analysis of 1,2,4-triazole and 3-amino-1,2,4-triazole as copper corrosion inhibitors in chloride solution, Corrosion Science, 77 (2013) 350-359. [57] M. Finšgar, J. Kovač, I. Milošev, Surface analysis of 1-hydroxybenzotriazole and benzoltriazole adsorbed on $\mathrm{Cu}$ by X-ray photoelectron spectroscopy, Journal of the Electrochemical Society, 157 (2010) C52-C60. 
[58] M. Finšgar, D.K. Merl, 2-Mercaptobenzoxazole as a copper corrosion inhibitor in chloride solution: Electrochemistry, 3D-profilometry, and XPS surface analysis, Corrosion Science, 80 (2014) 82-95.

[59] L.P. Kazansky, I.A. Selyaninov, Yu.I. Kuznetsov, Adsorption of 2-

mercaptobenzothiazole on copper surface from phosphate solutions, Applied Surface Science, 258 (2012) 6807-6813.

[60] F. Zucchi, A. Frignani, V. Grassi, G. Trabanelli, M. DalColle, The formation of a protective layer of 3-mercapto-propyl-trimethoxy-silane on copper, Corrosion Science, 49 (2007) 1570-1583.

[61] D. Chadwick, T. Hashemi, Electron spectroscopy of corrosion inhibitors: surface films formed by 2-mercaptobenzothiazole and 2-mercaptobenzimidazole on copper, Surface Science, 89 (1979) 649-659.

[62] S.K. Chawla, N. Sankarraman, J.H. Payer, Diagnostic spectra for XPS analysis of Cu-OS-H compounds, Journal of Electron Spectroscopy and Related Phenomena, 61 (1992) 1-18. [63] A. Galtayries, J.P. Bonnelle, XPS and ISS Studies on the Interaction of $\mathrm{H}_{2} \mathrm{~S}$ with Polycrystalline $\mathrm{Cu}, \mathrm{Cu}_{2} \mathrm{O}$ and $\mathrm{CuO}$ Surfaces, Surface and Interface Analysis, 23 (1995) 171179.

[64] B. Millet, C. Fiaud, C. Hinnen, E.M.M. Sutter, A correlation between electrochemical behaviour, composition and semiconducting properties of naturally grown oxide films on copper, Corrosion Science, 37 (1995) 1903-1918.

[65] R.F. Roberts, X-Ray photoelectron spectroscopic characterization of copper oxide surfaces treated with benzotriazole, Journal of Electron Spectroscopy and related phenomena, 4 (1974) 273-291.

[66] Handbook of X-ray Photoelectron Spectroscopy, Ed. G.E. Muilenberg, Perkin-Elmer Corporation, Eden Prairie, Minnesota (1979). 
[67] A.M. Beccaria, C. Bertolotto, Inhibitory action of 3-trimethoxysilylpropanethiol-1 on copper corrosion in $\mathrm{NaCl}$ solutions, ElectrochimicaActa, 42 (1997) 1361-1371.

[68] Y.S. Tan, M.P. Srinivasan, S.O. Pehkonen, S.Y.M. Chooi, Effects of ring substituents on the protective properties of self-assembled benzenethiols on copper, Corrosion Science 48 (2006) 840-862. 

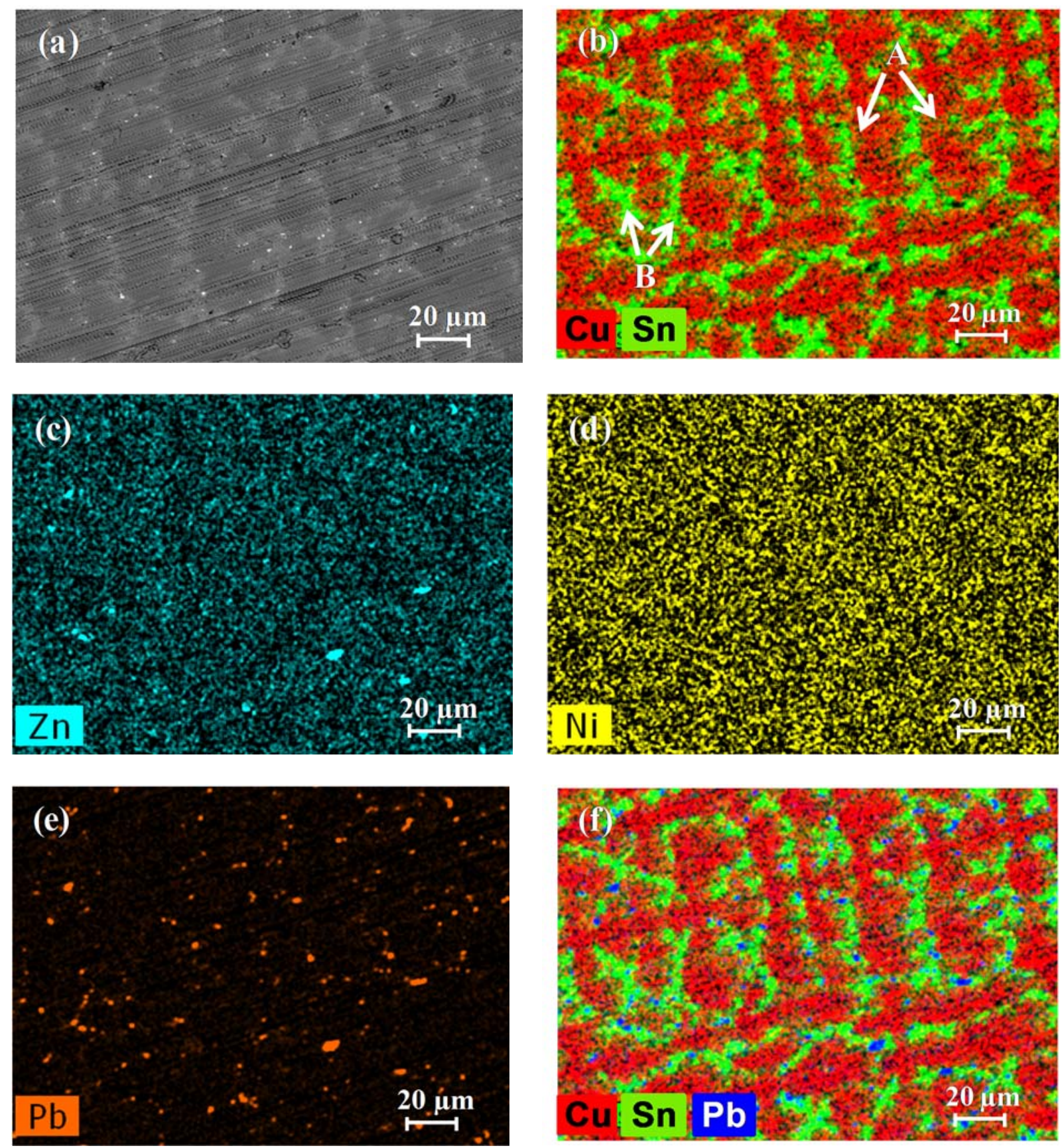

Figure 1: SEM micrograph of bronze (a) and EDX cartography of $\mathrm{Cu}-\mathrm{Sn}$ (b), Zn (c), Ni (d), $\mathrm{Pb}(\mathrm{e})$ and $\mathrm{Cu}-\mathrm{Sn}-\mathrm{Pb}$ showing regions $\mathrm{A}$ and $\mathrm{B}(\mathrm{f})$. 


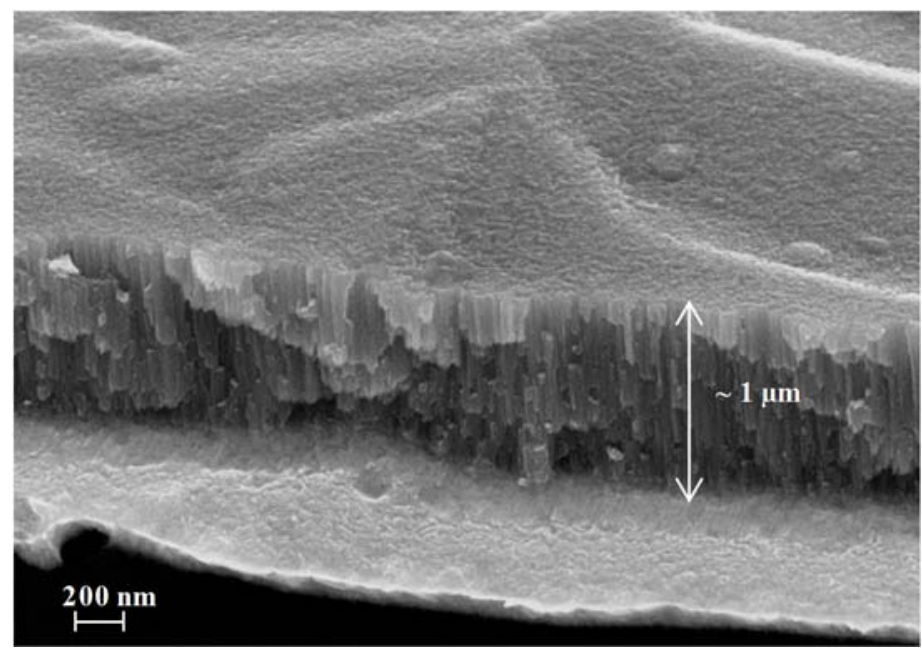

Figure 2: SEM micrograph of layer morphology deposited onto quartz electrode from bronze alloy target. 

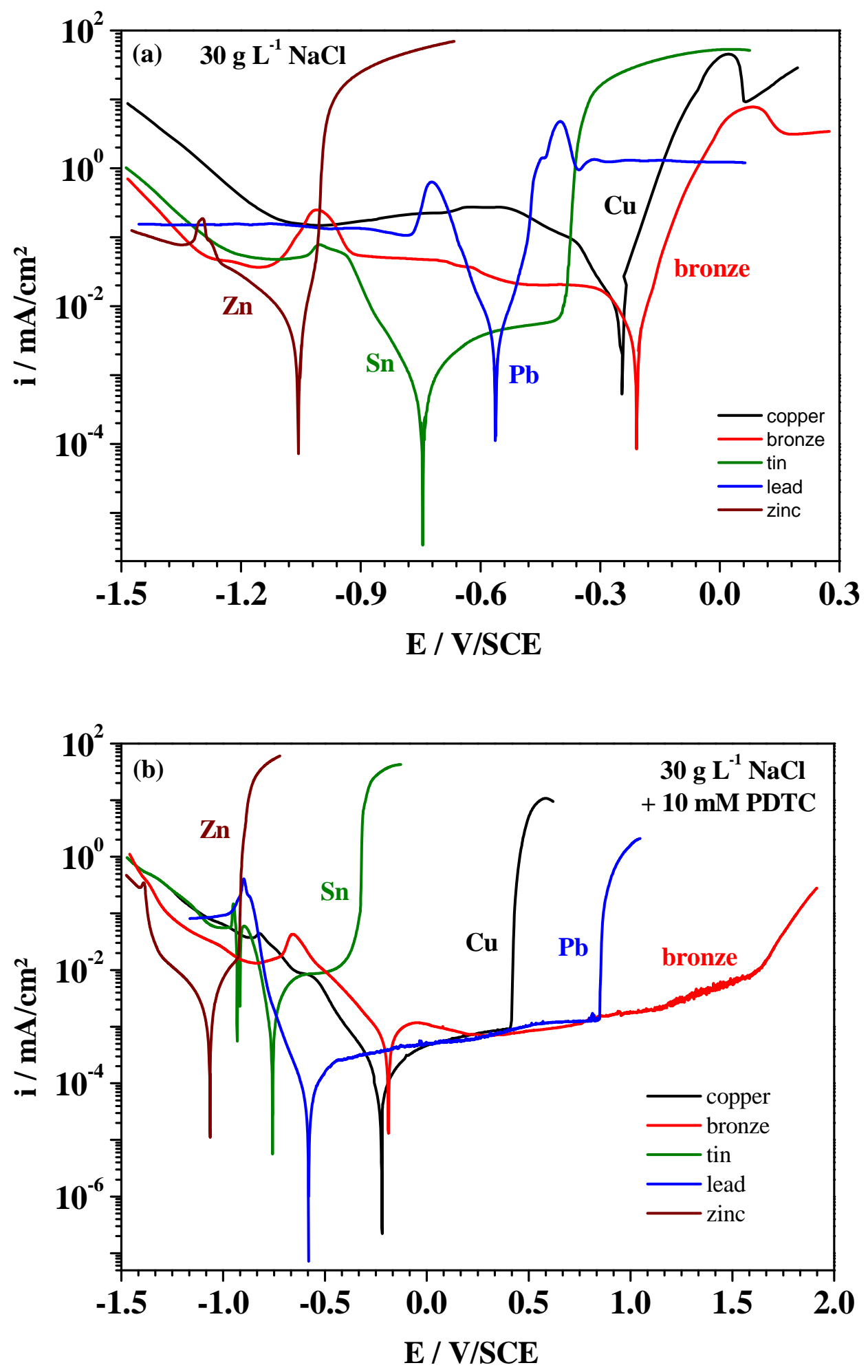

Figure 3: Polarization curves collected after one hour immersion of $\mathrm{Cu}$, bronze, $\mathrm{Sn}, \mathrm{Pb}$ and $\mathrm{Zn}$ electrodes in $30 \mathrm{~g} \mathrm{~L}^{-1} \mathrm{NaCl}$ without (a) or with $10 \mathrm{mM}$ PDTC (b) ; stationary electrodes at $20^{\circ} \mathrm{C}$. 


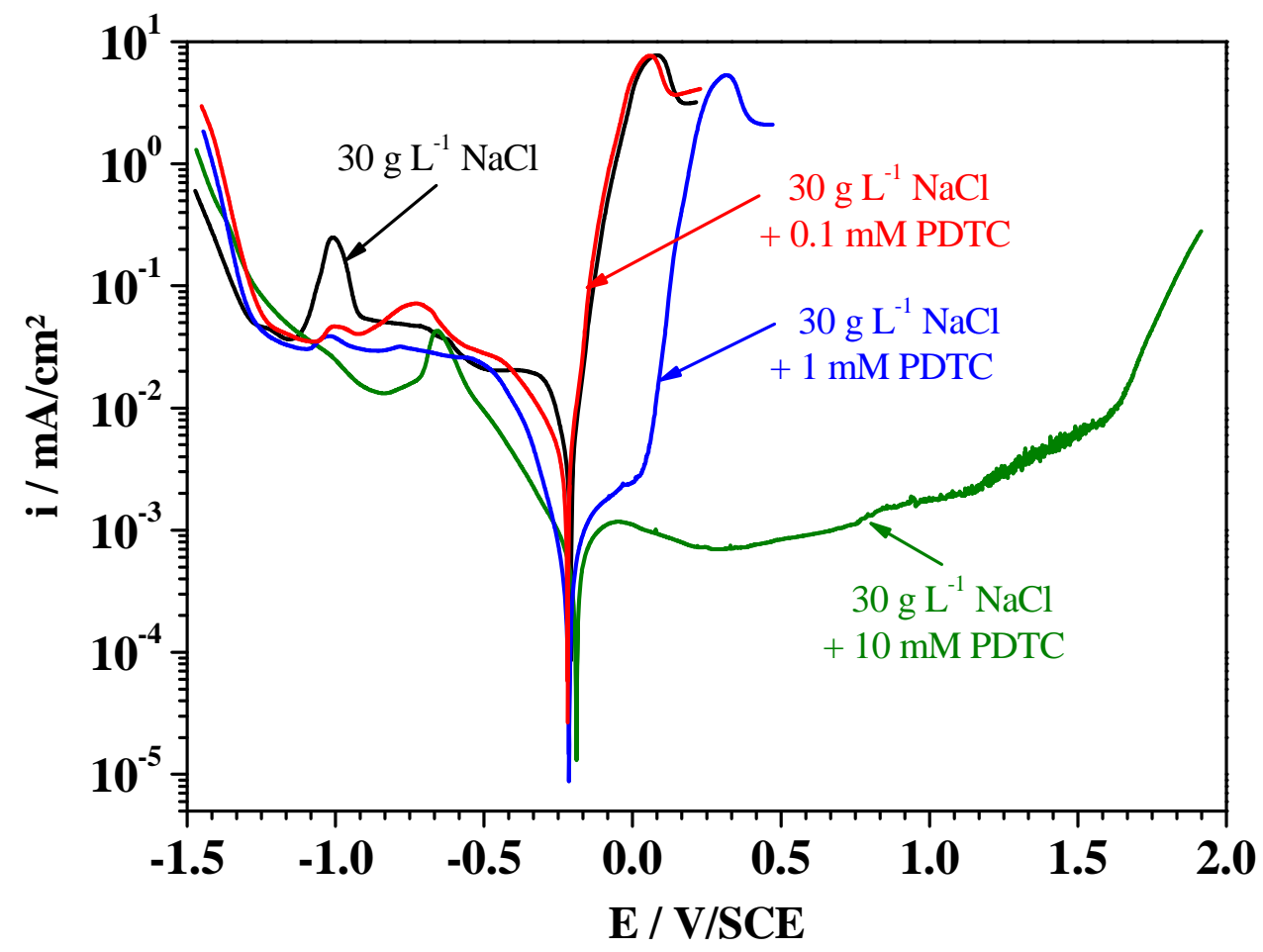

Figure 4: Effect of PDTC at different concentrations on the electrode kinetics of bronze electrode in $30 \mathrm{~g} \mathrm{~L}^{-1} \mathrm{NaCl}$; stationary electrode at $20^{\circ} \mathrm{C}$. 


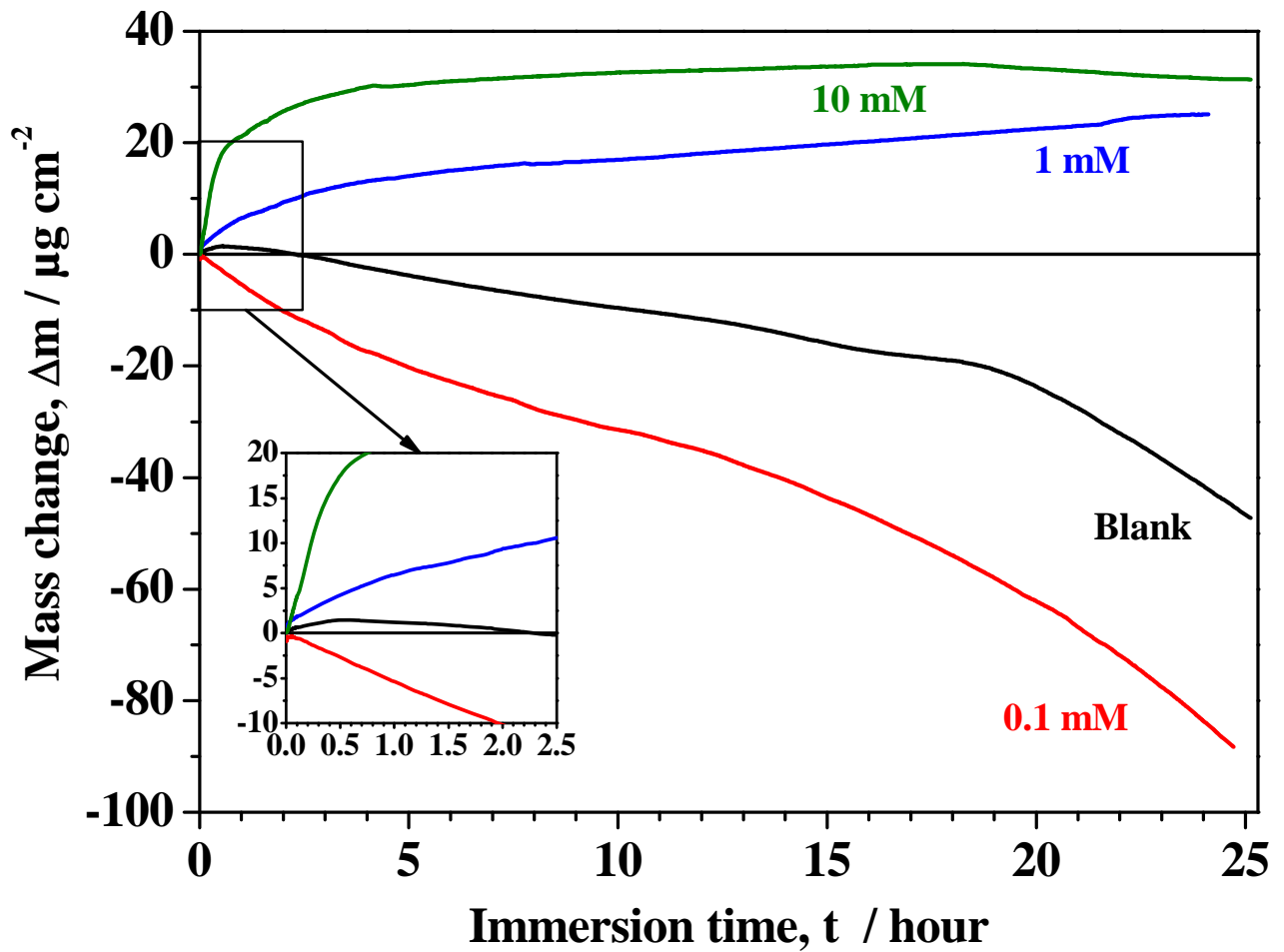

Figure 5: Gravimetric measurements on vapor deposited bronze in presence of different concentrations of PDTC in $30 \mathrm{~g} \mathrm{~L}^{-1} \mathrm{NaCl}$. The insert indicates an initial mass change in enlarged scale. 


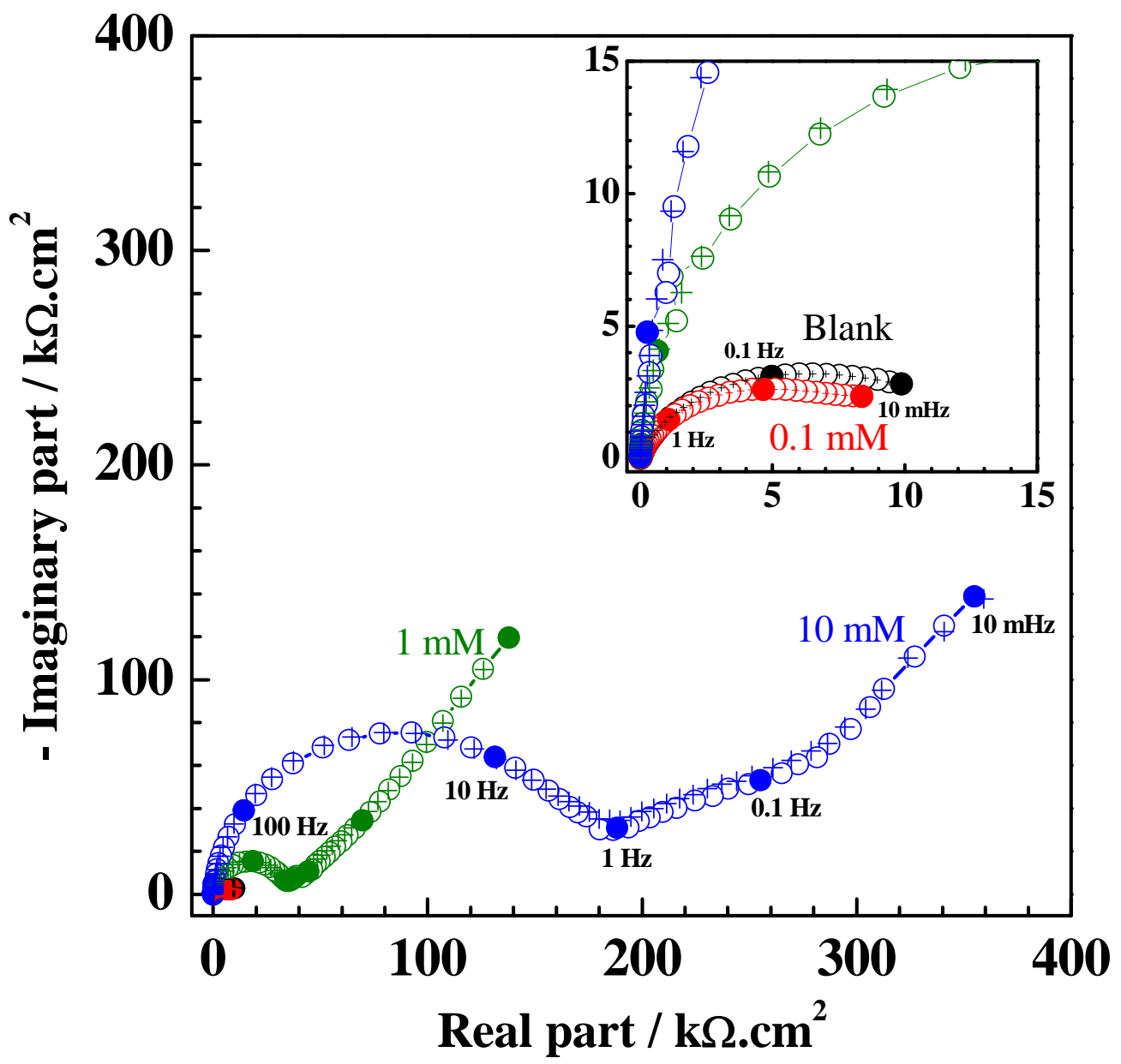

Figure 6: Nyquist diagrams of bronze after 24 hours exposure time in $30 \mathrm{~g} \mathrm{~L}^{-1} \mathrm{NaCl}+$ PDTC at different concentrations; stationary electrode at $20^{\circ} \mathrm{C}$.

Symbols = experimental data; and crosses $=$ calculated data.

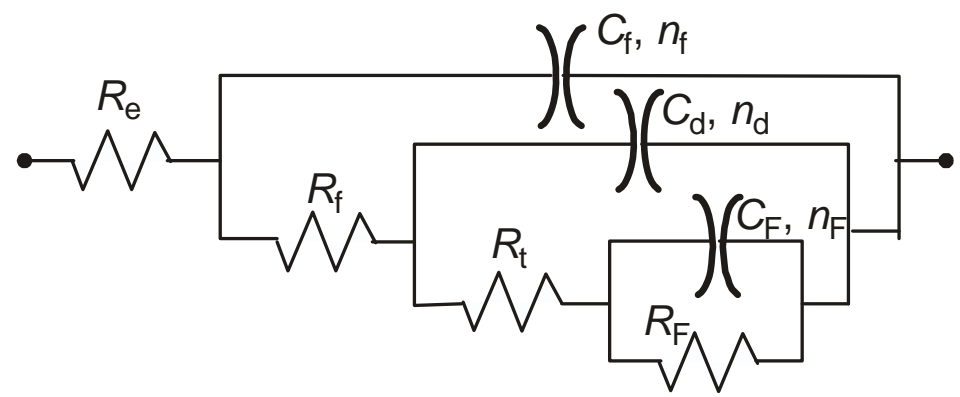

Figure 7: Electrical equivalent circuit to reproduce experimental impedance spectra for bronze electrode in $\mathrm{NaCl}$ solution without or with PDTC. 

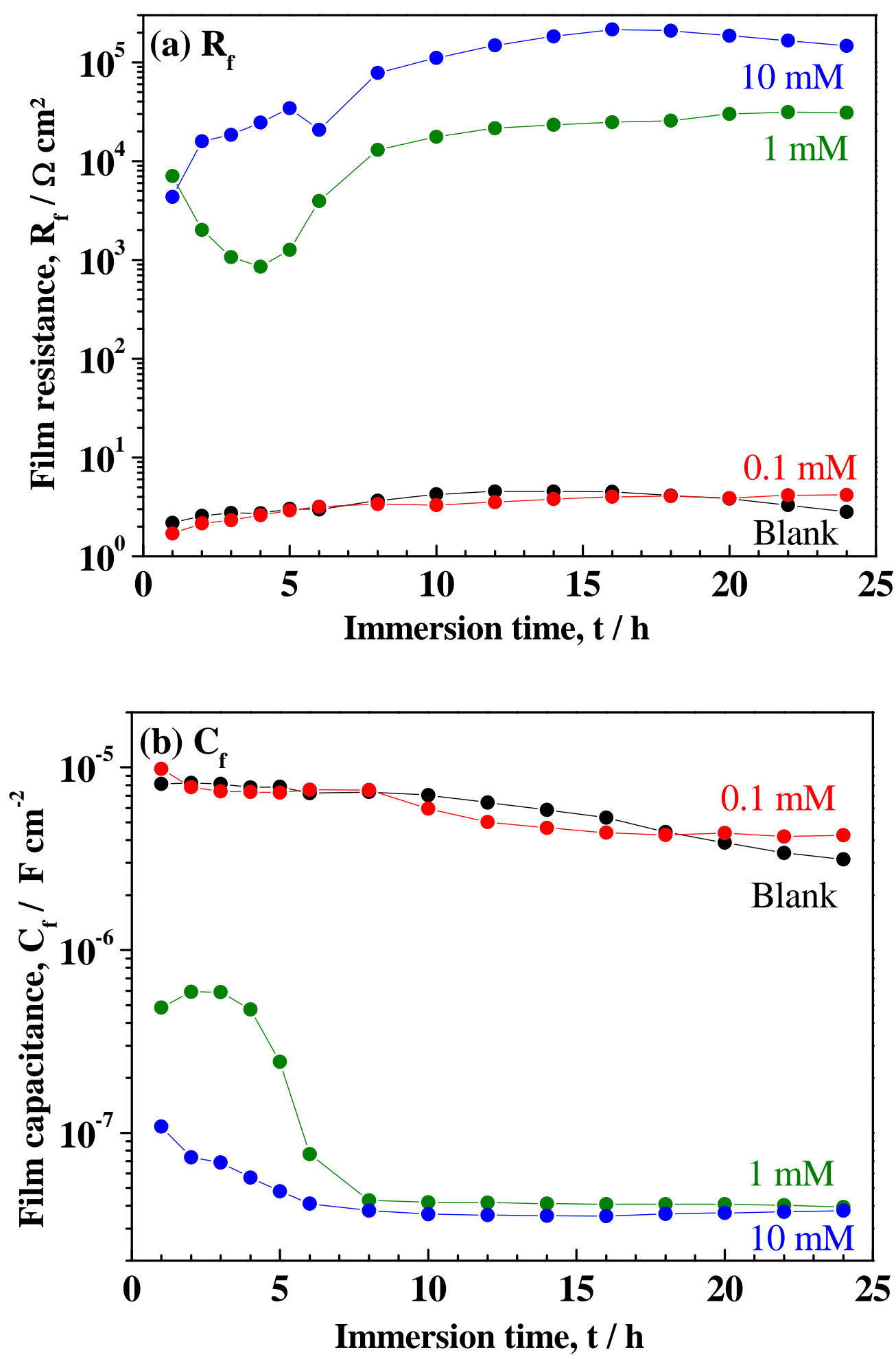

Figure 8: $R \mathrm{f}$ and $C_{\mathrm{f}}$ change as a function of immersion period for bronze / $30 \mathrm{~g} \mathrm{~L}^{-1} \mathrm{NaCl}+$ PDTC at different concentrations; stationary electrode at $20^{\circ} \mathrm{C}$. 

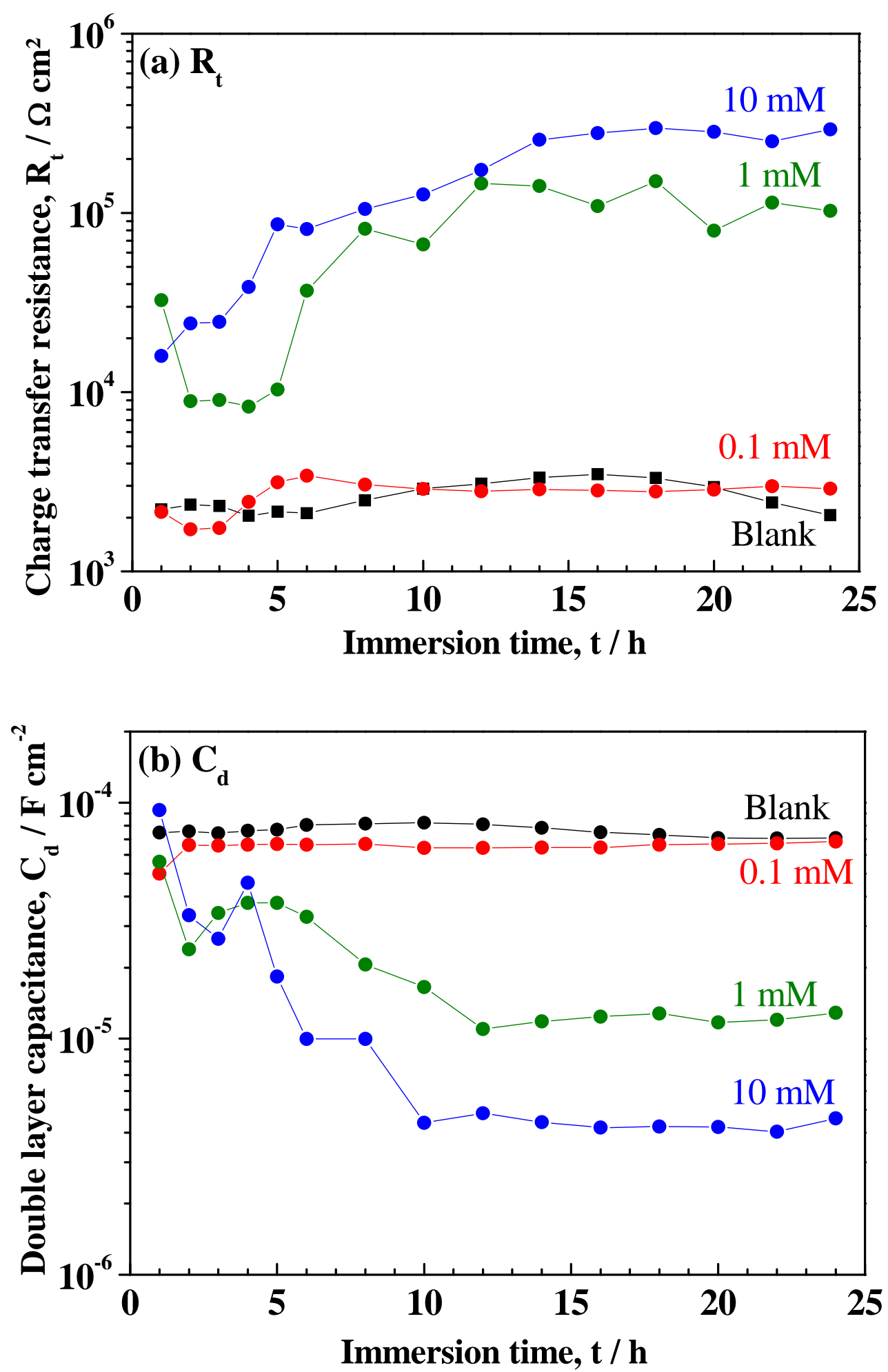

Figure 9: $R_{\mathrm{t}}$ and $C_{\mathrm{d}}$ change as a function of immersion time for bronze / $30 \mathrm{~g} \mathrm{~L}^{-1} \mathrm{NaCl}+$ PDTC at different concentrations; stationary electrode at $20^{\circ} \mathrm{C}$. 

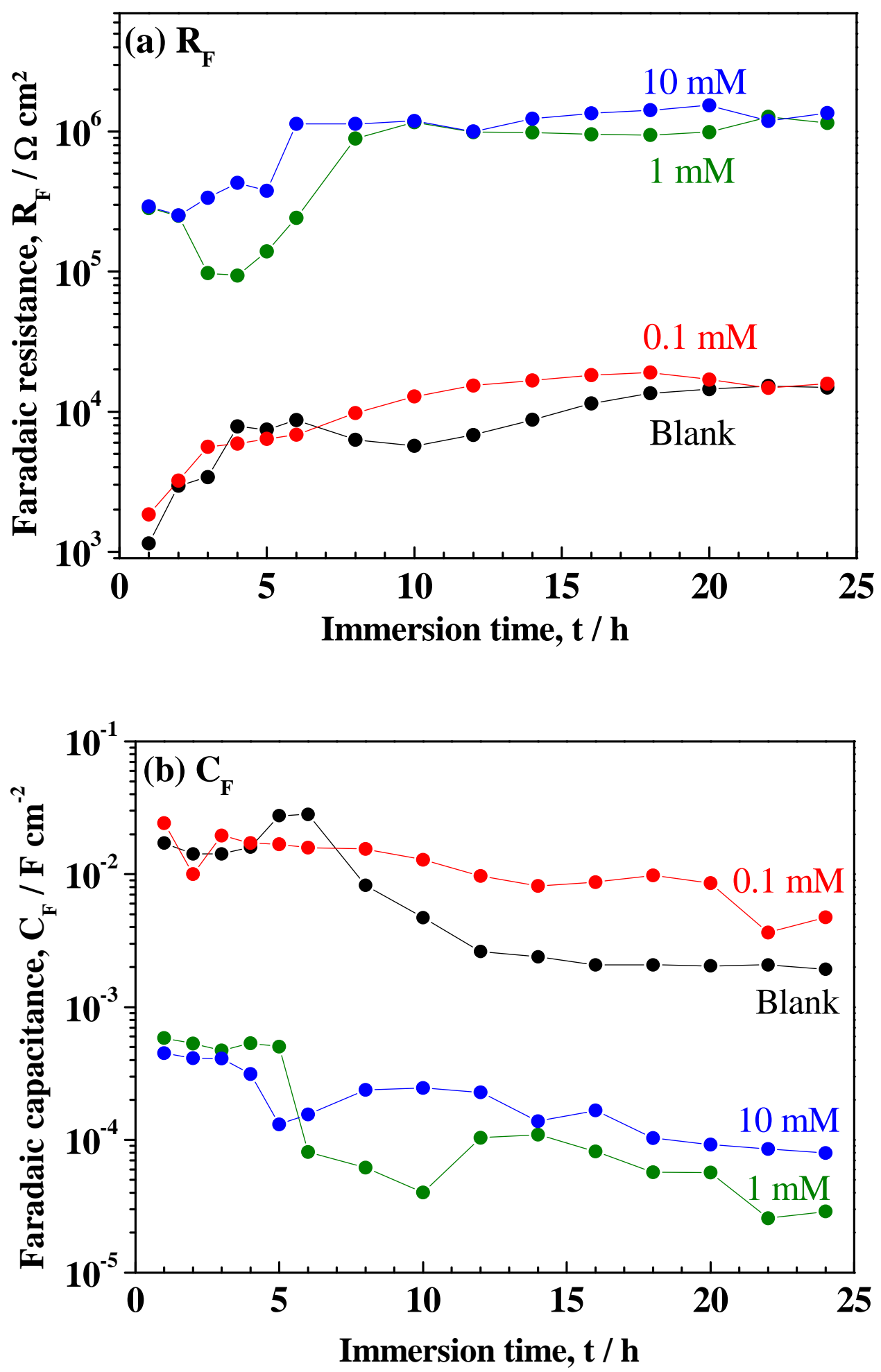

Figure 10: $R_{\mathrm{F}}$ and $C_{\mathrm{F}}$ change as a function of immersion time in bronze / $30 \mathrm{~g} \mathrm{~L}^{-1} \mathrm{NaCl}+$ PDTC at different concentrations; stationary electrode at $20^{\circ} \mathrm{C}$. 

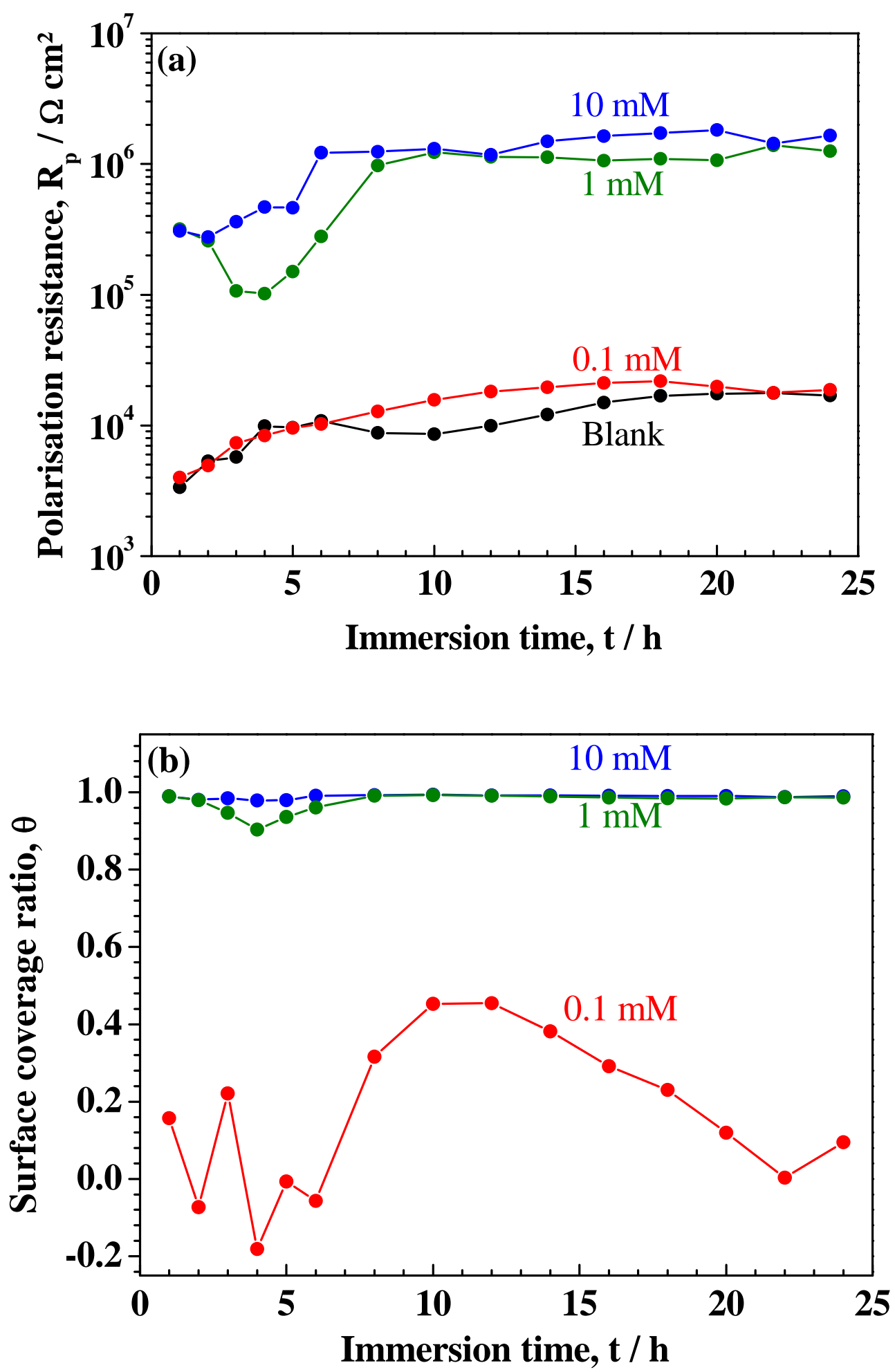

Figure 11: Variation of the polarization resistance $\mathrm{R}_{\mathrm{p}}(\mathrm{a})$ and the surface coverage ratio (b) with respect to the immersion time. Bronze / $30 \mathrm{~g} \mathrm{~L}^{-1} \mathrm{NaCl}+\mathrm{PDTC}$ at different concentrations; stationary electrode at $20^{\circ} \mathrm{C}$. 

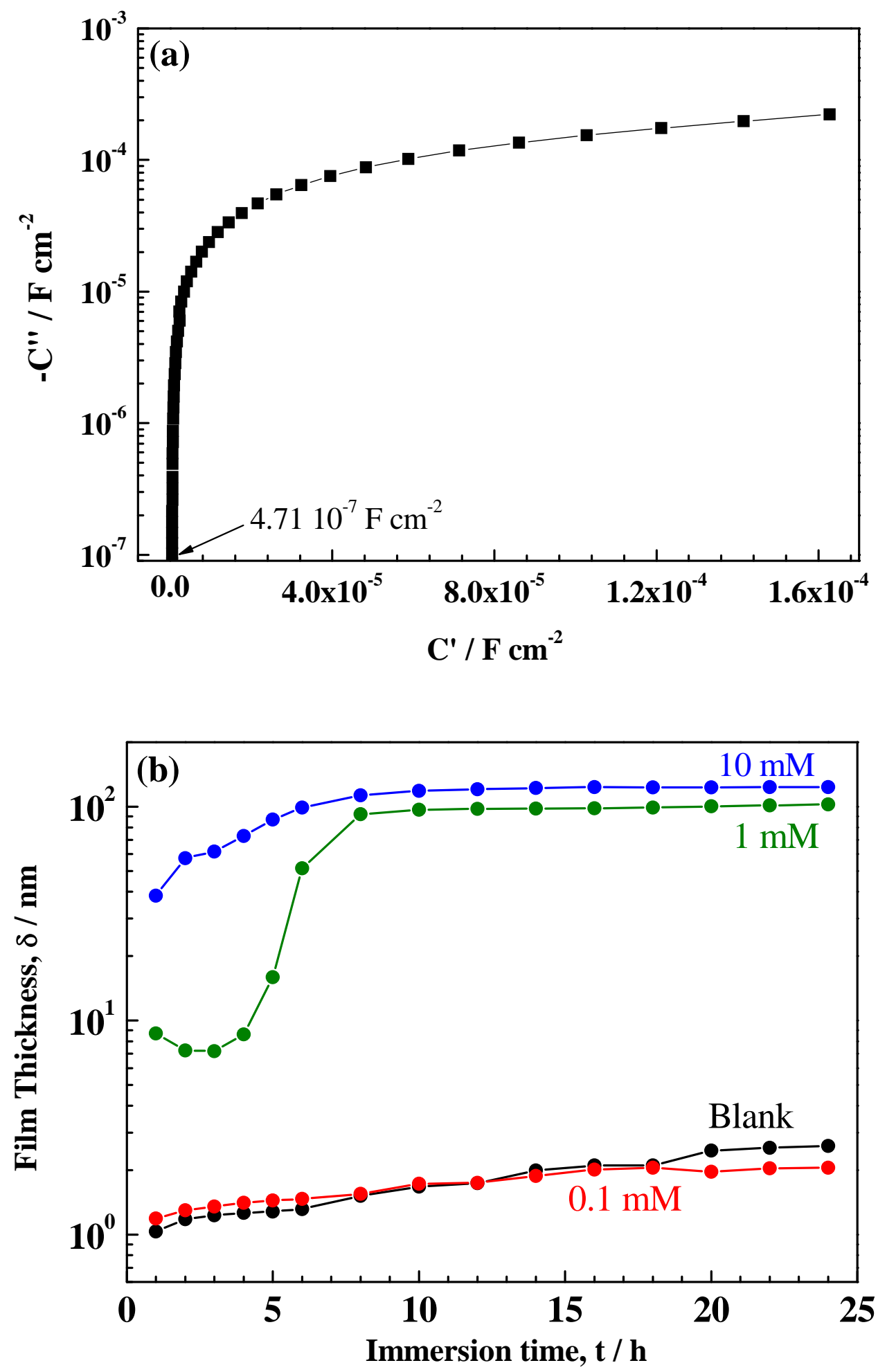

Figure 12: Cole-Cole plot in semi-log coordinates corresponding to EIS diagram of bronze after 1 hour immersion in $30 \mathrm{~g} \mathrm{~L}^{-1} \mathrm{NaCl}+1 \mathrm{mM}$ PDTC (a) and thickness of films formed on bronze as a function of immersion time in $30 \mathrm{~g} \mathrm{~L}^{-1} \mathrm{NaCl}+$ PDTC at different concentrations (b); stationary electrode at $20^{\circ} \mathrm{C}$. 

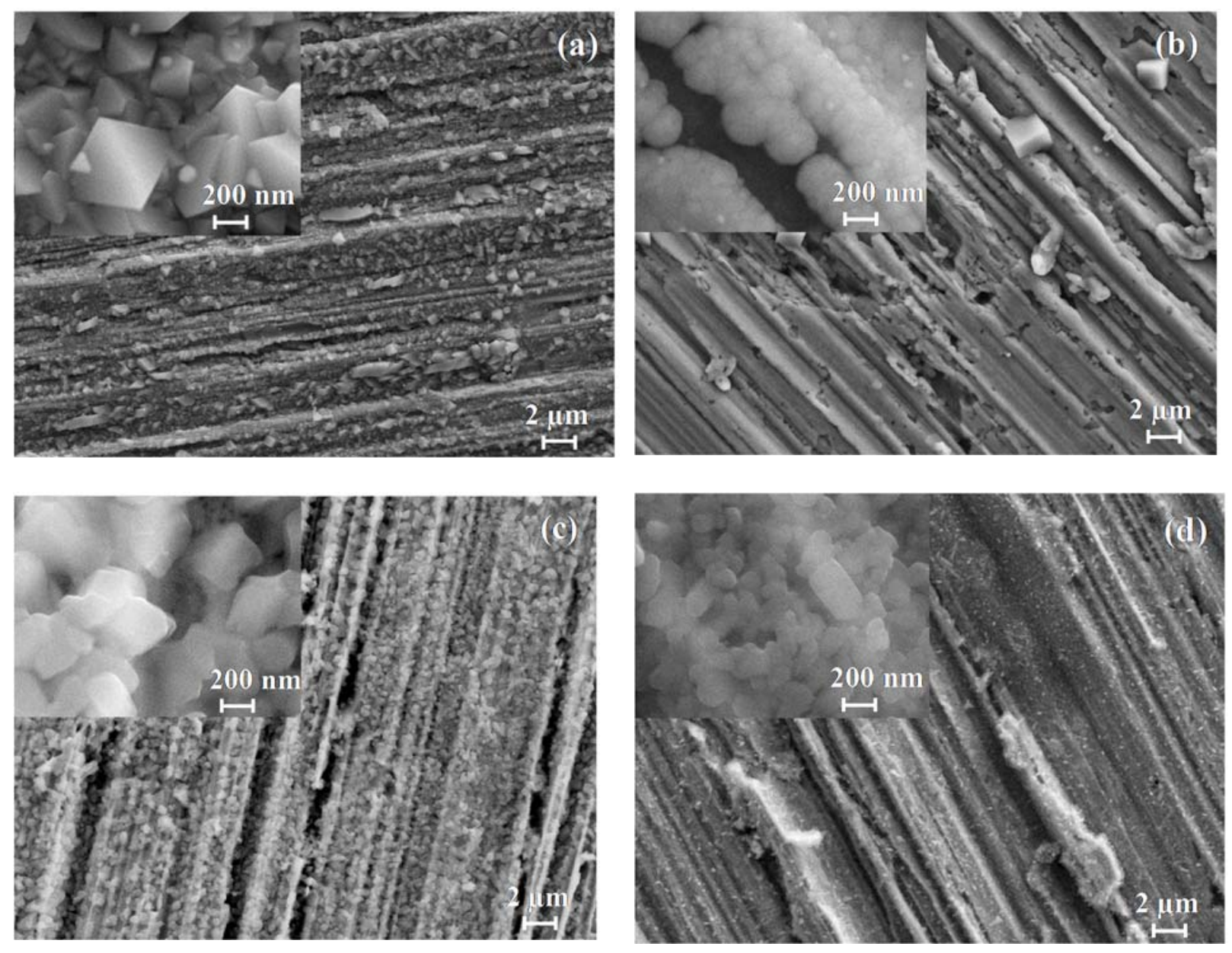

Figure 13: SEM images of bronze surface after $24 \mathrm{~h}$ immersion time in $30 \mathrm{~g} \mathrm{~L}^{-1} \mathrm{NaCl}$ without (a), with $0.1 \mathrm{mM}$ (b), $1 \mathrm{mM}$ (c) and $10 \mathrm{mM}$ PDTC (d). 


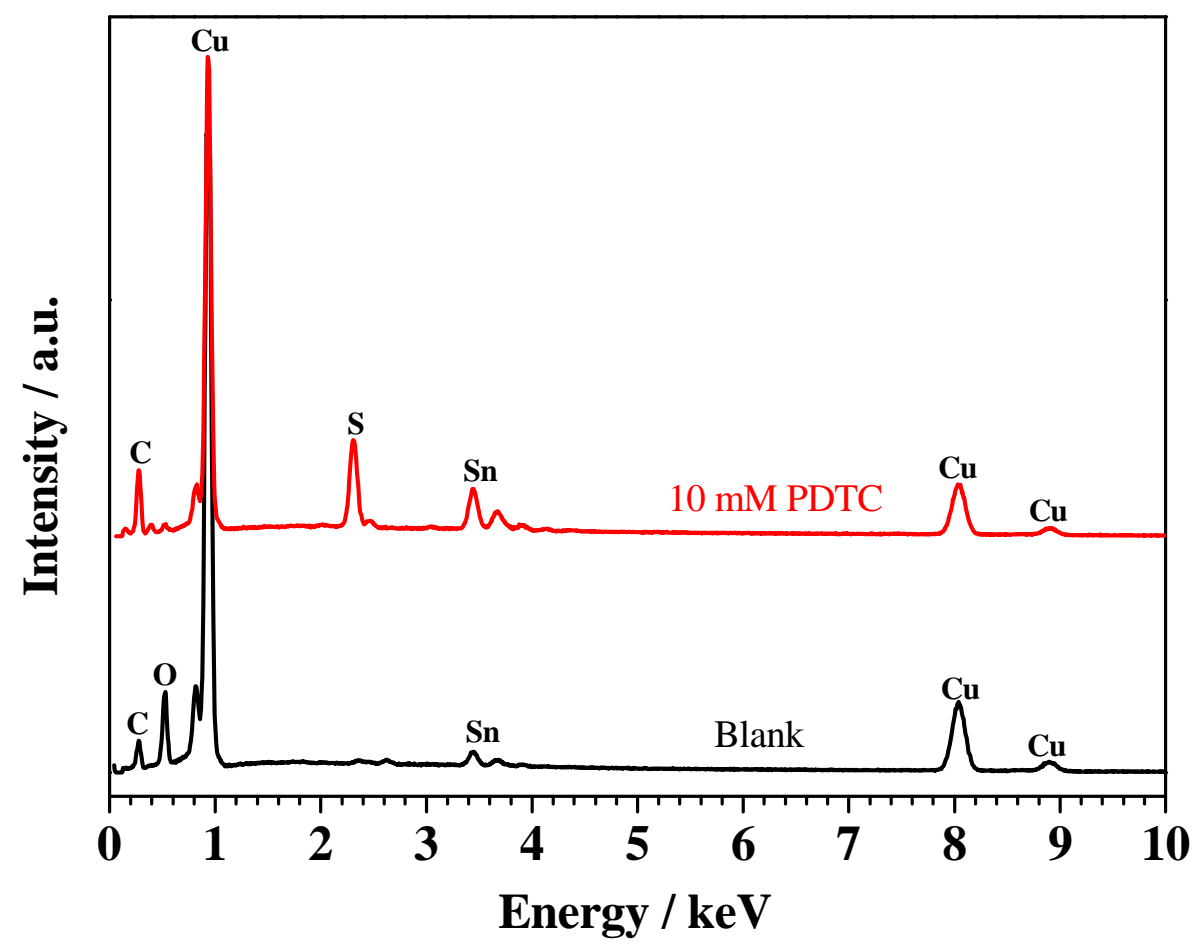

Figure 14: EDX analysis of bronze surface after $24 \mathrm{~h}$ immersion time in $30 \mathrm{~g} \mathrm{~L}^{-1} \mathrm{NaCl}$ without and with $10 \mathrm{mM}$ PDTC. 


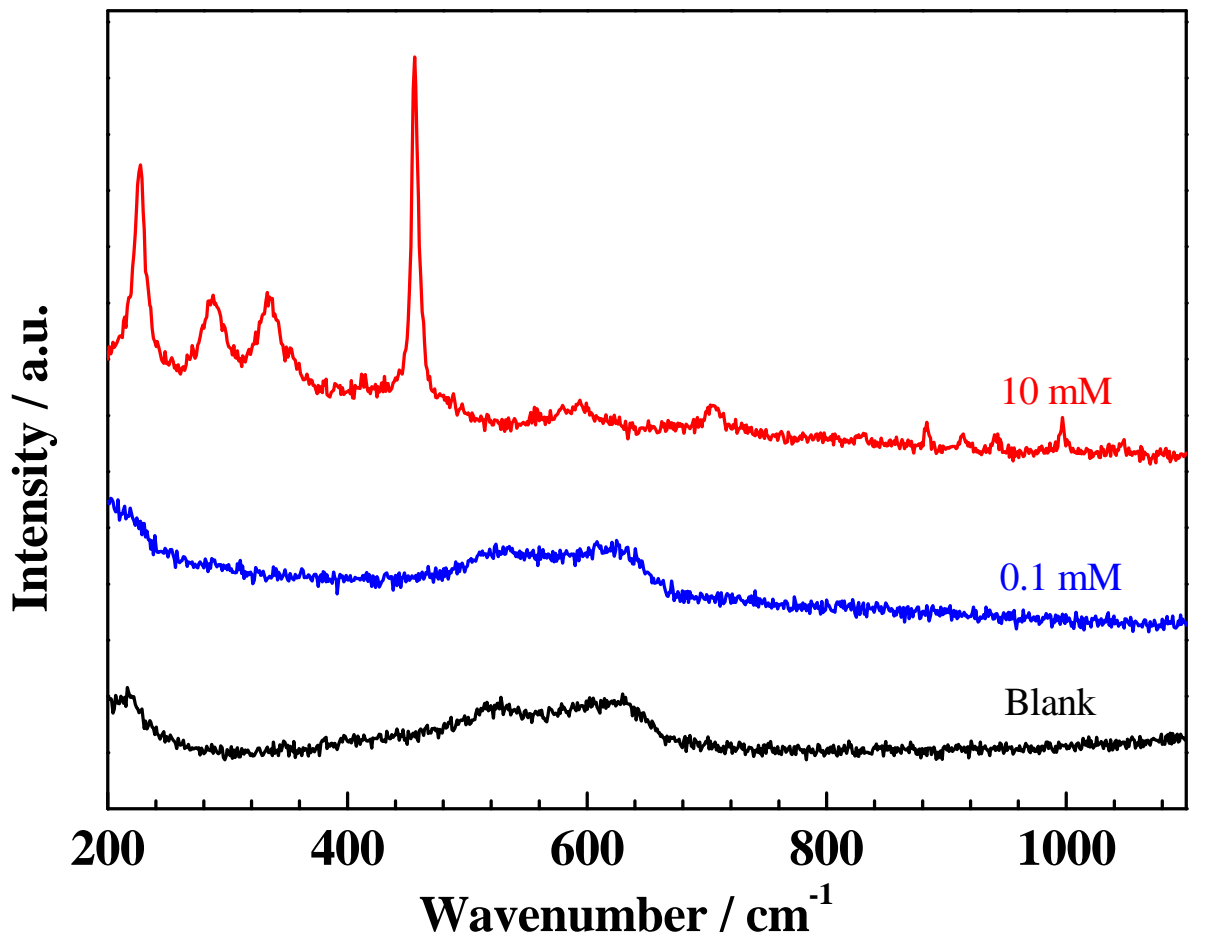

Figure 15: Raman spectra collected on bronze electrode after $24 \mathrm{~h}$ immersion in $30 \mathrm{~g} \mathrm{~L}^{-1} \mathrm{NaCl}$ without or with $0.1 \mathrm{mM}$ or $10 \mathrm{mM}$ PDTC. 


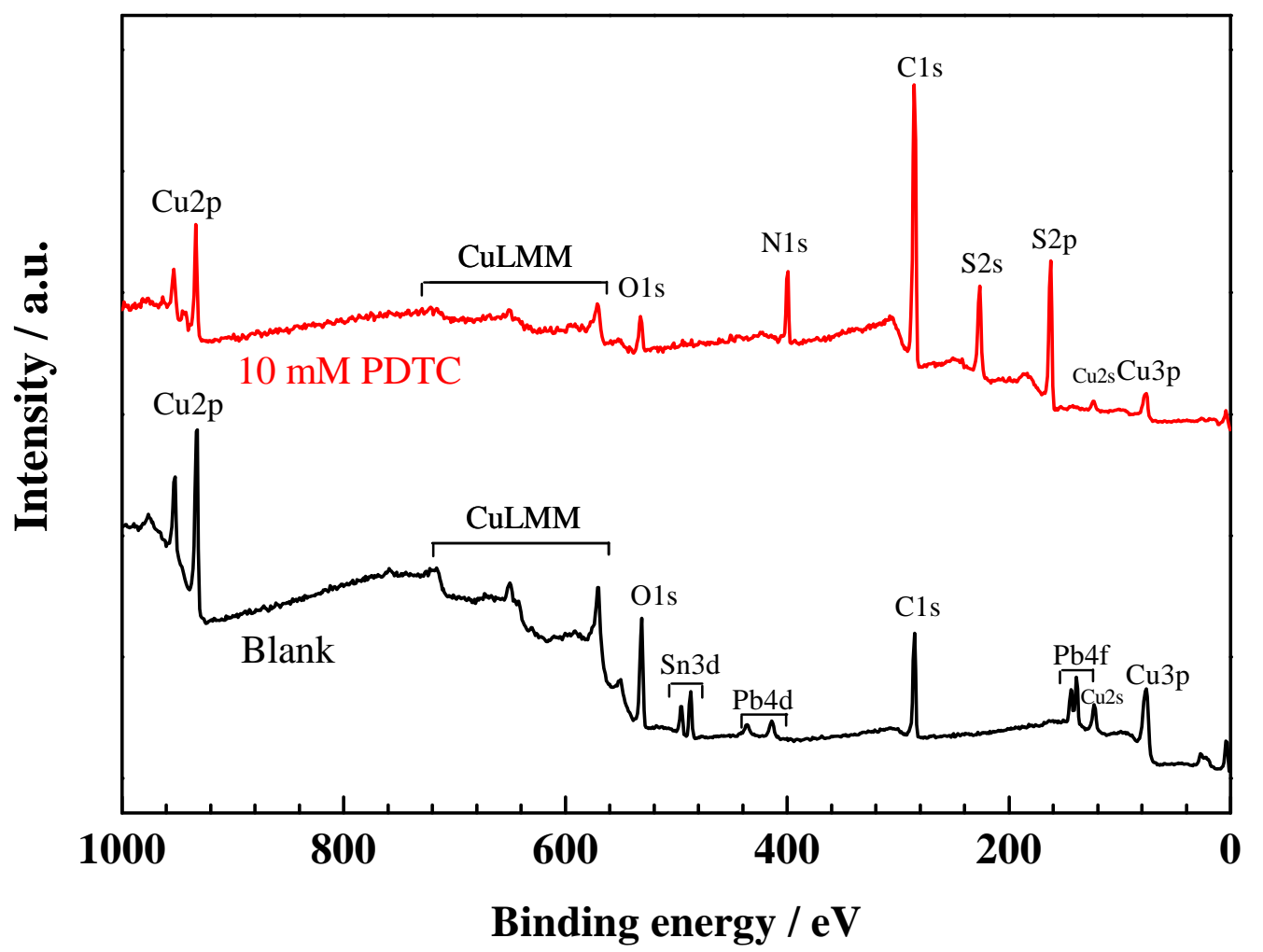

Figure 16: Survey XPS spectra of bronze electrode after $24 \mathrm{~h}$ immersion in $30 \mathrm{~g} \mathrm{~L}^{-1} \mathrm{NaCl}$ without or with $10 \mathrm{mM}$ PDTC. 

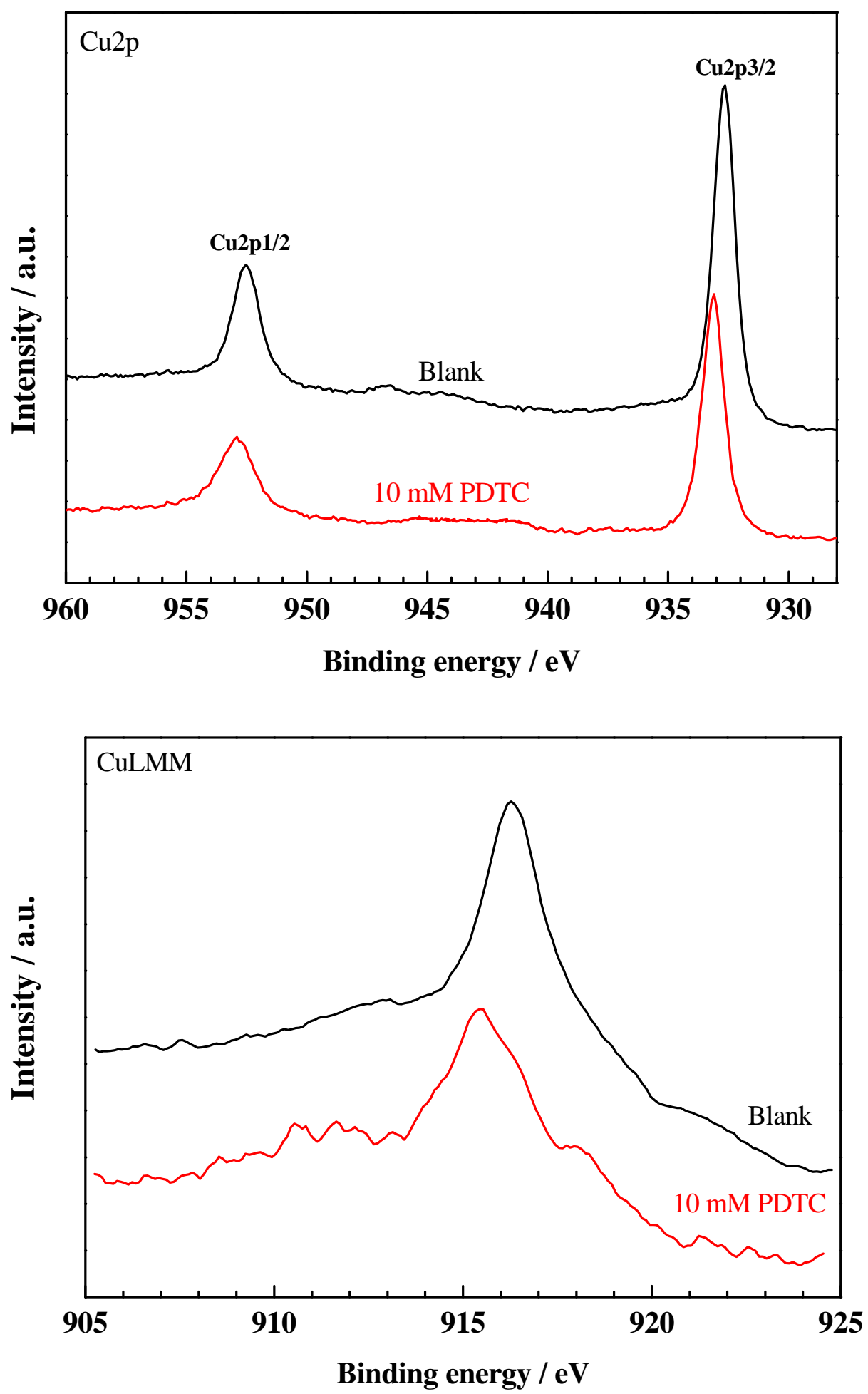

Figure 17: Cu2p and CuLMM spectra of bronze electrode after $24 \mathrm{~h}$ immersion in $30 \mathrm{~g} \mathrm{~L}^{-1}$ $\mathrm{NaCl}$ without or with $10 \mathrm{mM}$ PDTC. 

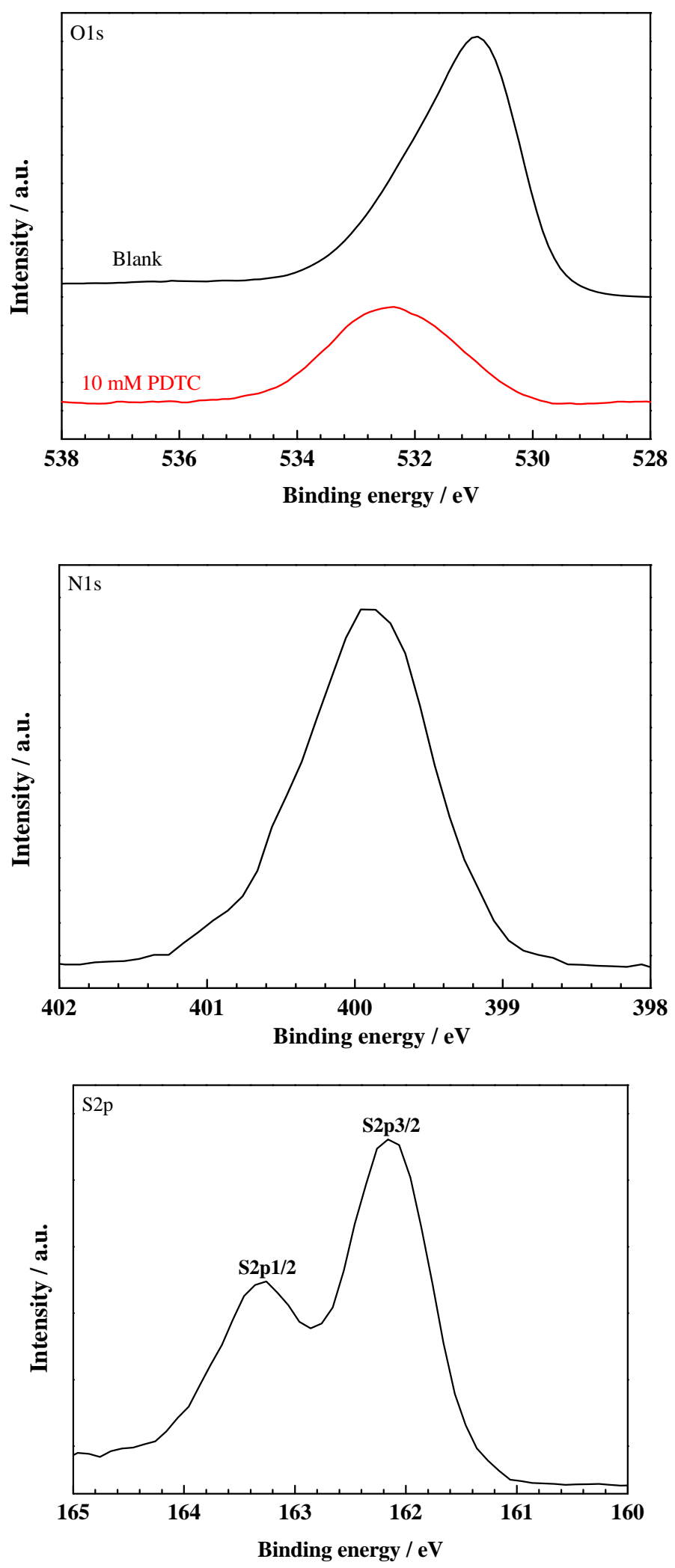

Figure 18: XPS spectra of different elements present on bronze electrode after $24 \mathrm{~h}$ immersion in $30 \mathrm{~g} \mathrm{~L}^{-1} \mathrm{NaCl}$ without or with $10 \mathrm{mM}$ PDTC. 
Table 1: Composition of the industrial bronze.

\begin{tabular}{cccccccccc}
\hline & $\mathrm{Cu}$ & $\mathrm{Sn}$ & $\mathrm{Zn}$ & $\mathrm{Pb}$ & $\mathrm{P}$ & $\mathrm{Ni}$ & $\mathrm{Fe}$ & $\mathrm{Al}$ & $\mathrm{Mn}$ \\
\hline $\mathrm{at} \%$ & 91.050 & 6.227 & 1.570 & 0.482 & 0.282 & 0.280 & 0.104 & 0.0123 & 0.00011 \\
\hline $\mathrm{wt} \%$ & 85.61 & 10.93 & 1.519 & 1.48 & 0.130 & 0.243 & 0.086 & 0.00491 & 0.00009 \\
\hline
\end{tabular}

Table 2: Composition (element with significant percentage) of region A and region B determined by EDX analysis.

\begin{tabular}{cccccc}
\hline & $\mathrm{Cu}$ & $\mathrm{Sn}$ & $\mathrm{Zn}$ & $\mathrm{Pb}$ & $\mathrm{Ni}$ \\
\hline $\begin{array}{c}\text { Cu-rich } \\
\text { dendrite core } \\
\left(\begin{array}{c}\text { Region A) } \\
\text { at\% }\end{array}\right.\end{array}$ & 95.77 & 2.83 & 0.79 & 0.18 & 0.43 \\
wt\% & 93.11 & 5.12 & 0.79 & 0.59 & 0.39 \\
\hline $\begin{array}{c}\text { Sn-rich } \\
\text { periphery } \\
\text { (Region B) } \\
\text { at\% }\end{array}$ & & & & & \\
& 85.83 & 12.81 & 0.32 & 0.58 & 0.46 \\
wt\% & 76.35 & 21.29 & 0.29 & 1.69 & 0.38 \\
\hline
\end{tabular}


Table 3: EDX analysis of bronze surface after 24 hours immersion in $30 \mathrm{~g} \mathrm{~L}^{-1} \mathrm{NaCl}$ without and with PDTC.

\begin{tabular}{ccccc}
\hline $\begin{array}{c}\text { Element } \\
\text { at } \%\end{array}$ & $30 \mathrm{~g} \mathrm{~L}^{-1} \mathrm{NaCl}$ & $\begin{array}{c}30 \mathrm{~g} \mathrm{~L}^{-1} \mathrm{NaCl} \\
+0.1 \mathrm{mM}^{2} \mathrm{PDC}\end{array}$ & $\begin{array}{c}30 \mathrm{~g} \mathrm{~L}^{-1} \mathrm{NaCl} \\
+1 \mathrm{mM} \mathrm{PDTC}^{2}\end{array}$ & $\begin{array}{c}30 \mathrm{~g} \mathrm{~L}^{-1} \mathrm{NaCl} \\
+10 \mathrm{mM} \text { PDTC }\end{array}$ \\
\hline $\mathrm{Cu}$ & 76.8 & 76.1 & 83.4 & 84.6 \\
$\mathrm{Sn}$ & 6.30 & 10.4 & 5.2 & 5.1 \\
$\mathrm{O}$ & 16.9 & 13.5 & 1.6 & 0.34 \\
$\mathrm{~S}$ & - & - & 9.8 & 10.0 \\
\hline
\end{tabular}

